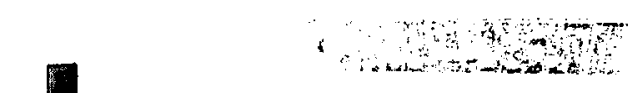

SUITE 201

GeothermEx, Inc.

DRILLING, LOGGING AND PRELIMINARY WELL TESTING

OF GEOTHERMAL WELL SUSAN 1,

SUSANVILLE, LASSEN COUNTY

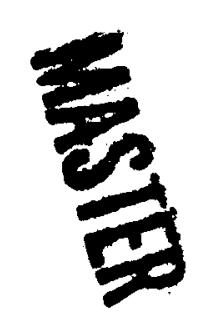

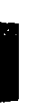
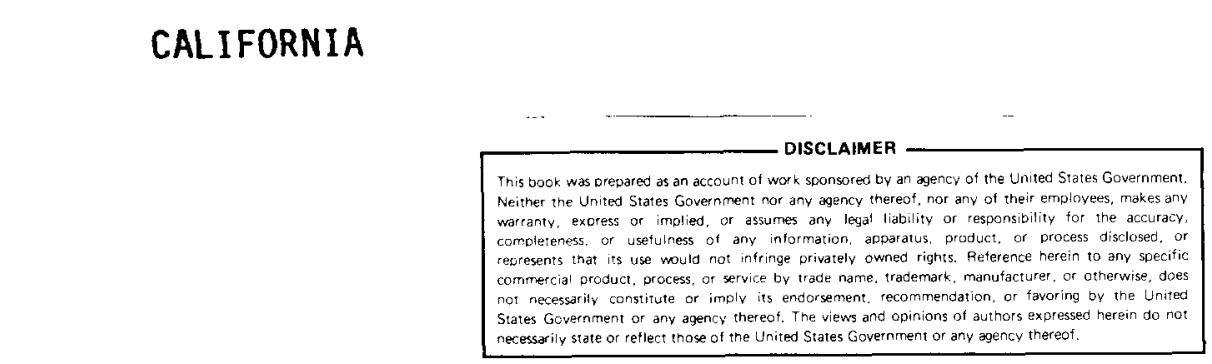

for

CITY OF SUSANVILLE,

SUSANVILLE, CALIFORNIA

DOE/ET/27040--T1

DE82 010444

by

GeothermEx, Inc.

Berkeley, California

James R. McNitt

Carol A. Petersen

Subir K. Sanyal

March, 1981 


\section{DISCLAIMER}

This report was prepared as an account of work sponsored by an agency of the United States Government. Neither the United States Government nor any agency Thereof, nor any of their employees, makes any warranty, express or implied, or assumes any legal liability or responsibility for the accuracy, completeness, or usefulness of any information, apparatus, product, or process disclosed, or represents that its use would not infringe privately owned rights. Reference herein to any specific commercial product, process, or service by trade name, trademark, manufacturer, or otherwise does not necessarily constitute or imply its endorsement, recommendation, or favoring by the United States Government or any agency thereof. The views and opinions of authors expressed herein do not necessarily state or reflect those of the United States Government or any agency thereof. 


\section{DISCLAIMER}

Portions of this document may be illegible in electronic image products. Images are produced from the best available original document. 


\section{CONTENTS}

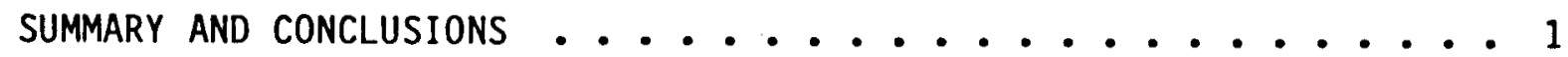

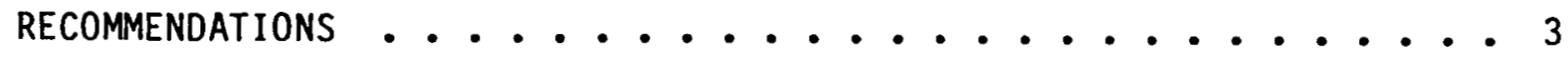

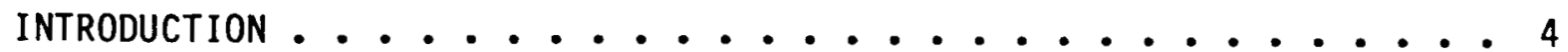

DRILLING HISTORY .................. 5

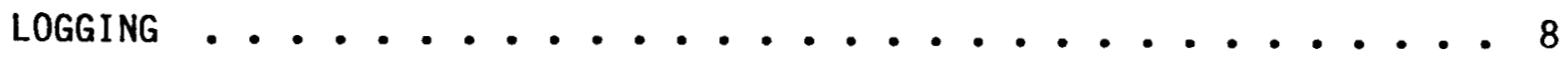

Drilling Logs .................. 8 Penetration Rate................ 8 Water Loss and Gain ................ 8 Return Temperature ............... 9

Formation Logs ................... 9

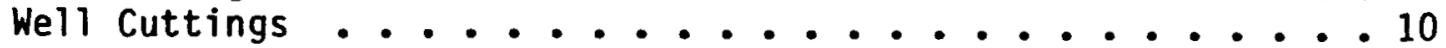

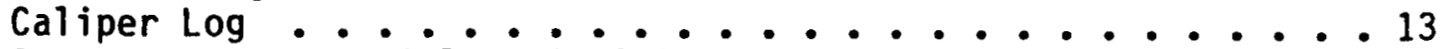
Spontaneous Potential-Resistivity Log .......... 13 Gamma Ray-Neutron Log .............. 13

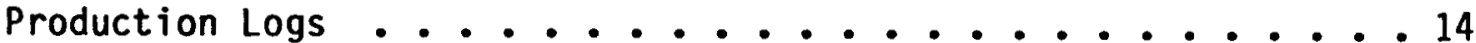

Temperature Logs ................. . . 14

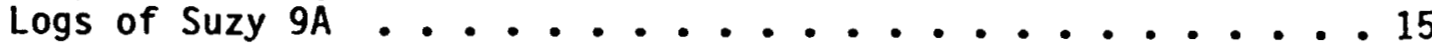

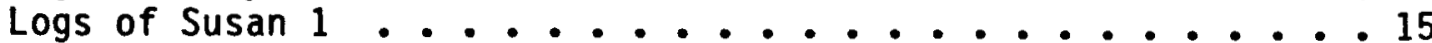

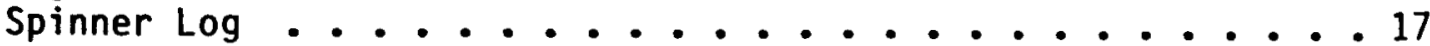

STRATIGRAPHIC SEQUENCE AND RESERVOIR CHARACTERISTICS

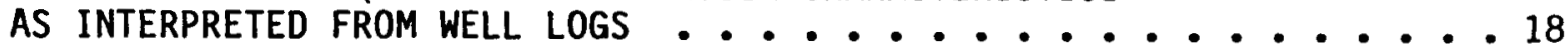

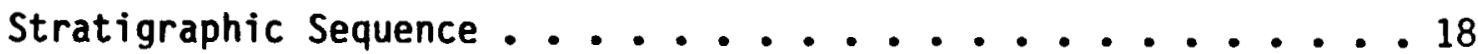

Nature and Thickness of Permeable Zones ......... 19

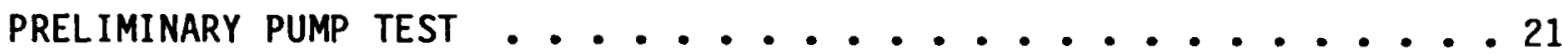

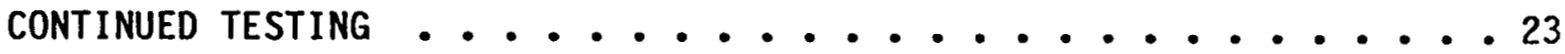

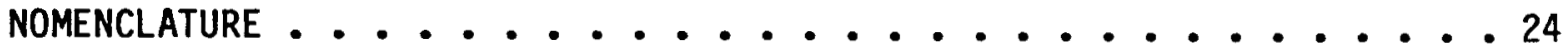

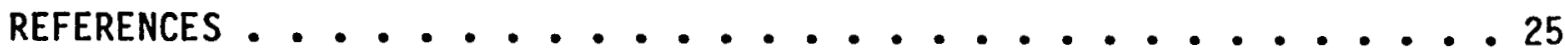




\section{APPENDIX}

A. Summary of Water Loss and Gain in Susan 1

B. Chemical Analyses of Water from Susan 1, Suzy 9A, and Nearby WeTls.

C. Lithologic Log of Susan 1

D. Copies of Geophysical Logs

E. Results of Pump Test of Susan 1, December 4-5, 1980 


\section{ILLUSTRATIONS}

Figure

After Page

1. Location of Well Susan 1.............. 4

2. Schematic Diagram of Reverse Drilling Process ....... 4

3. Susan 1 - Time Elapsed During Drilling and Completion . . - 5

4. Susan 1 - Final Well Dimensions ............ 5

5. Temperature Logs of Susan 1 and Suzy $9 A, 10 / 8 / 79$ Through 11/4/80 ................... 14

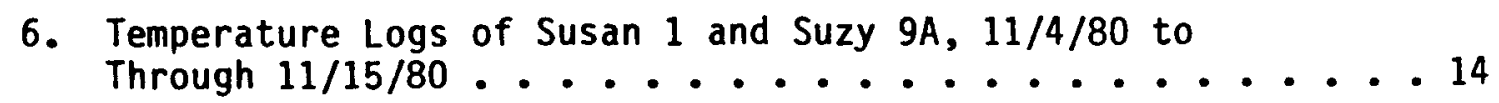

7. Deliverability of Susan 1 . . . . . . . . . . 21

8. Drawdown Test Analysis--Susan 1 . . . . . . . . 21

9. Pressure Buildup Test--250 gpm Case . . . . . . . . . 21

10. Pressure Buildup Analysis--350 gpm Case . . . . . . . 21

Table

1. Sequence of Logs in Susan 1 . . . . . . . . . . . 9

2. Results of Preliminary Pump Test of Susan 1 . . . . . 21

\section{Plate}

1. Lithology, Drilling Rate, and Mud Return Temperatures

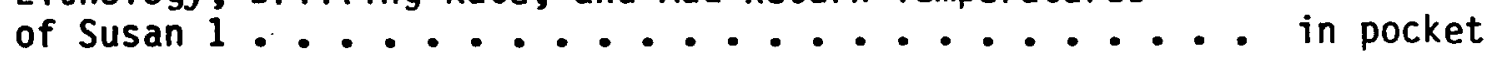

2. Temperature Logs of Susan 1 and Suzy $9 A$........ in pocket 


\section{SUMMARY AND CONCLUSIONS}

Susan 1, a hot water production well, was drilled late in 1980 for the City of Susanville, California, as part of its geothermal spaceheating project. This report presents a history of drilling, logging, completion and pump testing of this well. Susan 1 was drilled to 930 feet using local river water with a 17-1/2-inch bit from 50-540 feet and a 12-1/2-inch bit from 540-927 feet. A 12-3/4-inch solid casing was set from surface to 350 feet, a slotted casing from 350-538 feet, and a 8-5/8-inch slotted casing from 520-925 feet.

Interpretations of the following logs and test data from this well are presented:

1. drilling logs (penetration rate, water loss and gain, return temperatures);

2. formation logs (description of well cuttings, caliper, spontaneous potential, electrical resistivity, gamma ray, neutron);

3. production logs (temperature, spinner); and

4. pump test data.

Based on these interpretations the following stratigraphic sequence was identified in this well:

$\begin{array}{lll}\text { alluvial section } & - & 0-75 \text { feet } \\ \text { lake beds(?) } & - & 75-280 \text { feet } \\ \text { tuffs(?) } & - & 280-700 \text { feet } \\ \text { lake beds(?) } & - & 700-750 \text { feet } \\ \text { basaltic andesite } & - & 750-815 \text { feet } \\ \text { lake beds(?) } & - & 815-895 \text { feet } \\ \text { basalt } & - & 895-915 \text { feet } \\ \text { lake beds(?) } & - & 915-930 \text { feet }\end{array}$

Drilling conditions were more severe than anticipated, resulting in numerous partial cave-ins of the uncased hole. Future drilling will require a modified casing and completion program.

Permeable zones in the interval 350-460 feet constitute the aquifer, within the probable tuff interval. Permeable zones appear to exist below 825 feet from mud return temperatures; this could not be confirmed because of the inability to run logs below this depth. 
The transmissivity value from the pump test is on the order of $1.5 \times 10^{6} \mathrm{md} \cdot \mathrm{feet} / \mathrm{cp}$ and agrees with that from the wells in the southern part of the city. The storativity value from the pump test is on the order of $3 \times 10^{-5} \mathrm{ft} / \mathrm{psi}$ and is about one-tenth of that from the wells in the southern part of the city. Despite this, deliverability is comparable to that of other thermal wells in the area, at 10.5-12.6 $\mathrm{gpm} / \mathrm{ft}$. Maximum flow temperature of $174^{\circ} \mathrm{F}$ is some $10^{\circ} \mathrm{F}$ above the temperature anticipated prior to drilling.

The observed high flow rates (up to $650 \mathrm{gpm}$ for short intervals, and sustainable at $350 \mathrm{gpm}$ with just over 30 feet of drawdown), high temperature (flow at $174^{\circ} \mathrm{F}$, extrapolated equilibrium of at least $\left.180^{\circ} \mathrm{F}\right)$, and high deliverability at least equal to the pre-drilling expectations, and categorize Susan 1 as a successful geothermal well. 


\section{RECOMMENDATIONS}

1. Conduct at least a month-long, carefully designed interference test in which Susan 1 is flowed and the water level is monitored in a number of strategically selected wells in the city.

2. Develop a detailed correlation of logs, well data and pump test data from all wells in the city and develop a geological model of the reservoir.

3. Interpret the interference test data based on above geological model, and develop a quantitative reservoir model based from this. Use this reservoir model to assess reservoir capacity and to forecast long-term well performance.

4. Based on the reservoir model and operational constraints, decide on the need for and siting of (1) a second production well and (2) an injection wel1. Redesign drilling, casing and completion programs to satisfy anticipated conditions of caving formations. 
Susan 1 is a hot water production well drilled as part of the City of Susanville Geothermal Energy Project (DE AC03 79ET 27040). It is located in SE1/4 NE1/4 SE $1 / 4$ Sec. 31, T. $30 \mathrm{~N}$., R. $12 \mathrm{E}$. (Figure 1). Ground elevation is 4,210 feet; the hole is 925 feet deep. Susan 1 is about 15 feet northeast of Suzy $9 \mathrm{~A}$ and about 50 feet southwest of Suzy 9, which were drilled to 818 and 445 feet respectively in 1979.

The drilling contractor was the Water Development Corporation of Woodland, California. A trailer-mounted Failing JED-A reverse-circulation drilling rig was used. Unlike a conventional system, drilling fluid in a reverse circulation drilling rig flows downward by gravity from the surface around the drill stem, passes through the drill bit, and is pumped up inside the drill stem (Figure 2). Lift is provided by compressed air injected into the top 20-200 feet of the drill string. Reverse-circulation drilling provides very clean samples with little contamination from up-hole slough.

Water for drilling was pumped from the Susan River into a pit located next to the rig. This water, and the entrained sand-and siltsized drill cuttings in the circulation loop, was the only drilling fluid used; no mud, gel, foam or lost-circulation material was added. Water flowed by gravity from the pit through a short horizontal pipe into an 8-inch porthole cut into the surface casing, and thence down the hole (Figure 2). This pipe and porthole were about 4 feet below ground level.

Susan 1 was drilled in the period October 15-December 2, 1980. Drilling operations were conducted 24-hours per day until October 31 , with either 2 or 3 two-man crews per day. Well clean-out, setting of casing, and rig repair was done only during daylight hours after 0ctober 31. The drilling supervisor was Roger Weidemeir of the Water Development Corporation.

GeothermEx, Inc. was responsible for the specification, monitoring and supervision of drilling, logging, completion and flow testing. Carol A. Petersen of GeothermEx performed geologic logging during drilling operations, examined local surface geology and conducted temperature logging of Susan 1 and Suzy 9A. Dr. Subir K. Sanyal and Dr. James R. McNitt were present during geophysical logging of Susan 1 , provided well-site interpretation of the logs, and selected the interval to be completed with slotted 12-3/4-inch casing. Following completion, GeothermEx personnel conducted further logging and flow testing, interpreted the logs and tests, and prepared this report. 

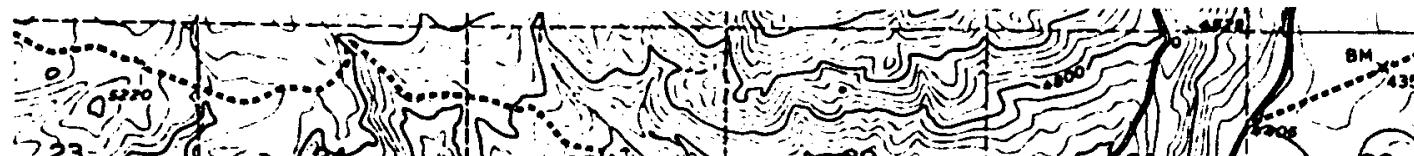

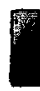

T. $30 \mathrm{~N}$.

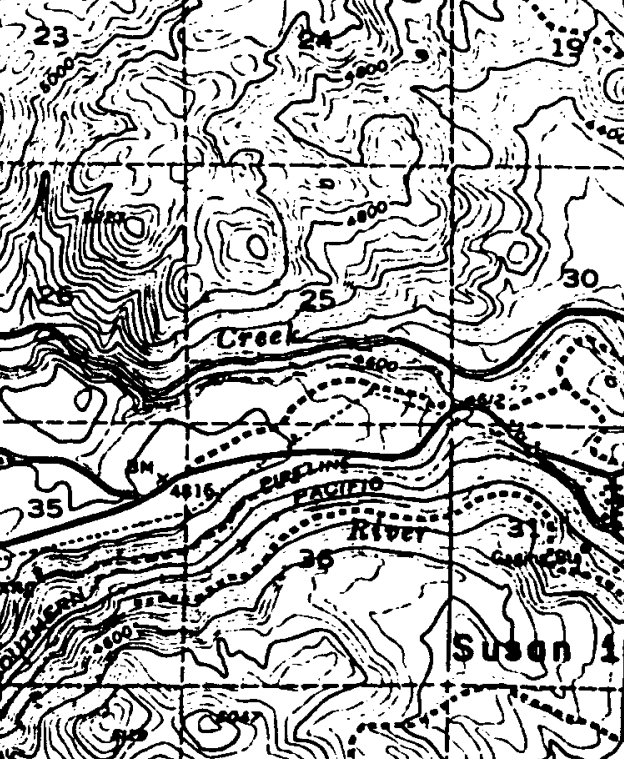

T. $29 \mathrm{~N}$

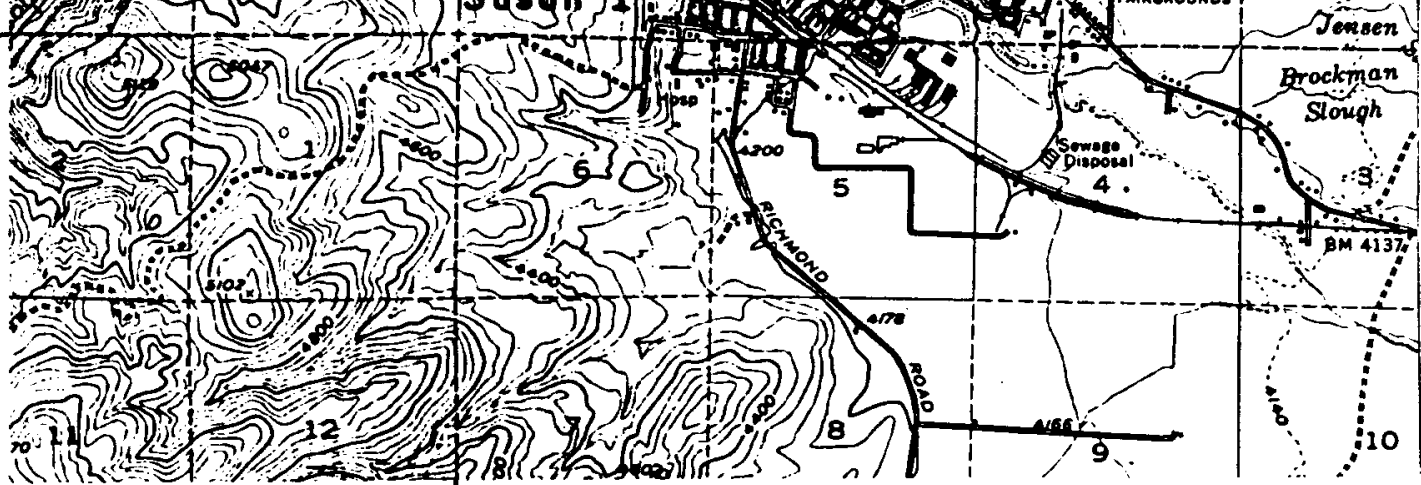

R. $11 \mathrm{E}$.

R. $12 \mathrm{E}$.

FIGURE 1. Location of Well Susan 1. 


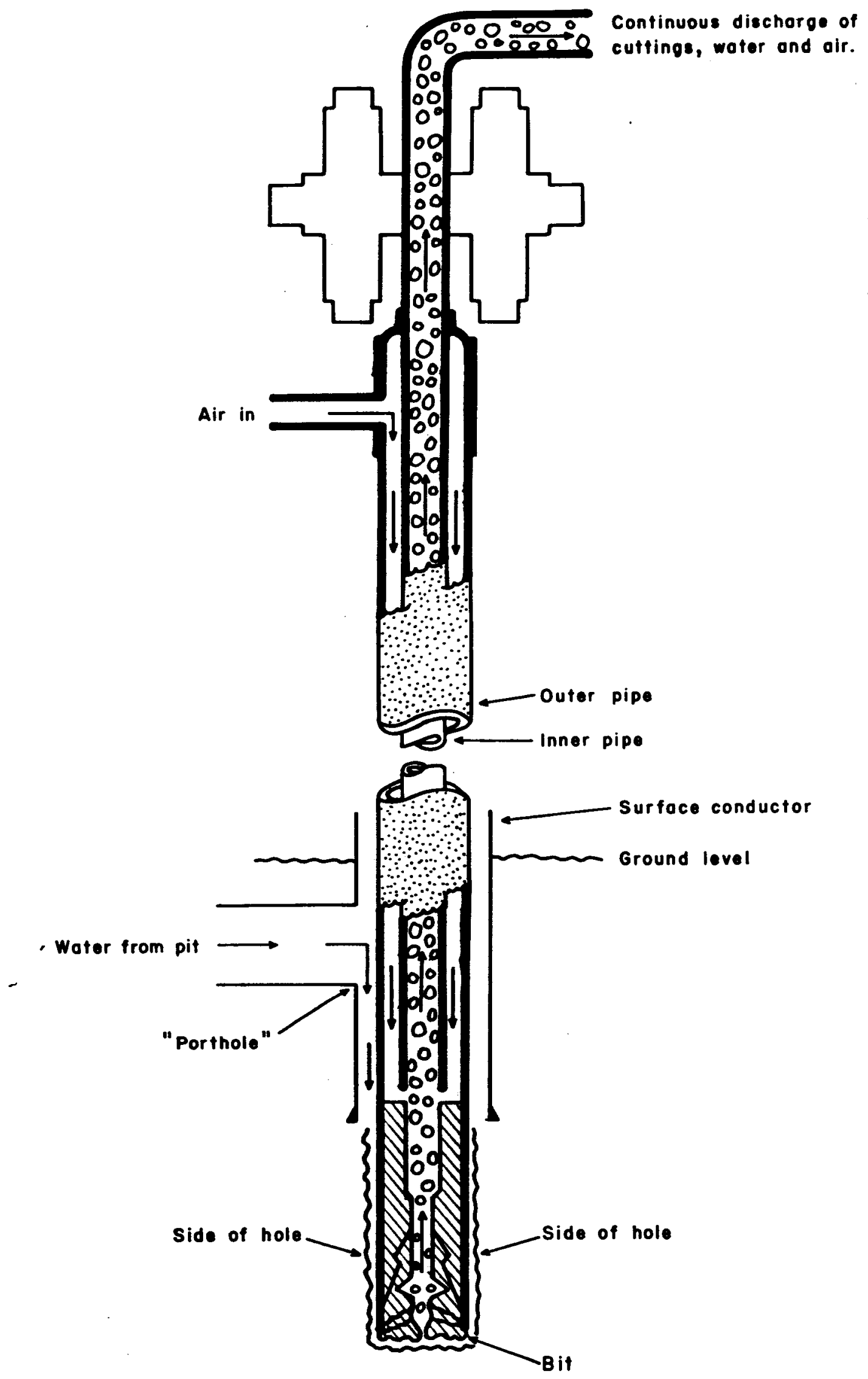

FIGURE 2. Schematic diagram of reverse drilling process. 


\section{DRILLING HISTORY}

Activities carried out during the drilling and casing period (October 15-December 2) are shown graphically in Figure 3. The final hole dimensions, as well as casing, slotted liner, cementing, and gravel pack intervals, are shown in Figure 4.

The hole was spudded on October 15 and drilled through finegrained to very coarse fluvial sediments to a 50 -foot depth with a 26 inch-diameter drag bit. Fifty feet of 20-inch conductor pipe was inserted and cemented into the hole. Coarse, poorly cemented fluvial gravels, cobbles and boulders were encountered to a depth of 75 feet. These coarse sediments caved into the hole beneath, and eventually from behind, the surface conductor, until finally the conductor was swinging free, suspended only by chains from the rig. Caving of the top 75 feet of poorly cemented sediments eventually produced a large hole ( $10 \times 3 \times 5$ feet) at the ground surface, fortuitously on the side away from the drill rig. If this hole had developed beneath a wheel or jack support, the rig would have overturned and the hole would have been lost.

If more holes are drilled near the Susan River, drilling specifications should allow flexibility in choosing the depth at which surface conductor is set. Experience at Susan 1 shows that caving results if river gravels are not cased off.

The hole was drilled below 50 feet with a 17-1/2-inch rock bit. Drilling rates were slow until lake beds(?) were encountered below the fluvial gravels. Drilling proceeded steadily to a depth of 360 feet, when caving uphole in the interval 240-260 feet began to endanger the drill string. Cleaning and circulating at 240-260 feet did not succeed in stabilizing the hole, so a cement plug was set. This plug is thought to cover the interval 235-260 feet, but there are no data to determine the actual interval covered by the cement.

After cleaning out the hole from 260-360 feet, drilling proceeded smoothly with the 17-1/2-inch bit. This was changed to a 12-1/2-inch rock bit at 540 feet, primarily because of drill string weight considerations and also because drilling specifications permitted a smaller diameter in the bottom of the hole. There was no lithologic break nor other geological consideration that required a change in drilling practices.

While drilling ahead with the $12-1 / 2$-inch bit, a very large lost-circulation zone developed when the hole was 475 feet deep. Water losses in previous intervals had been increasing steadily, as 


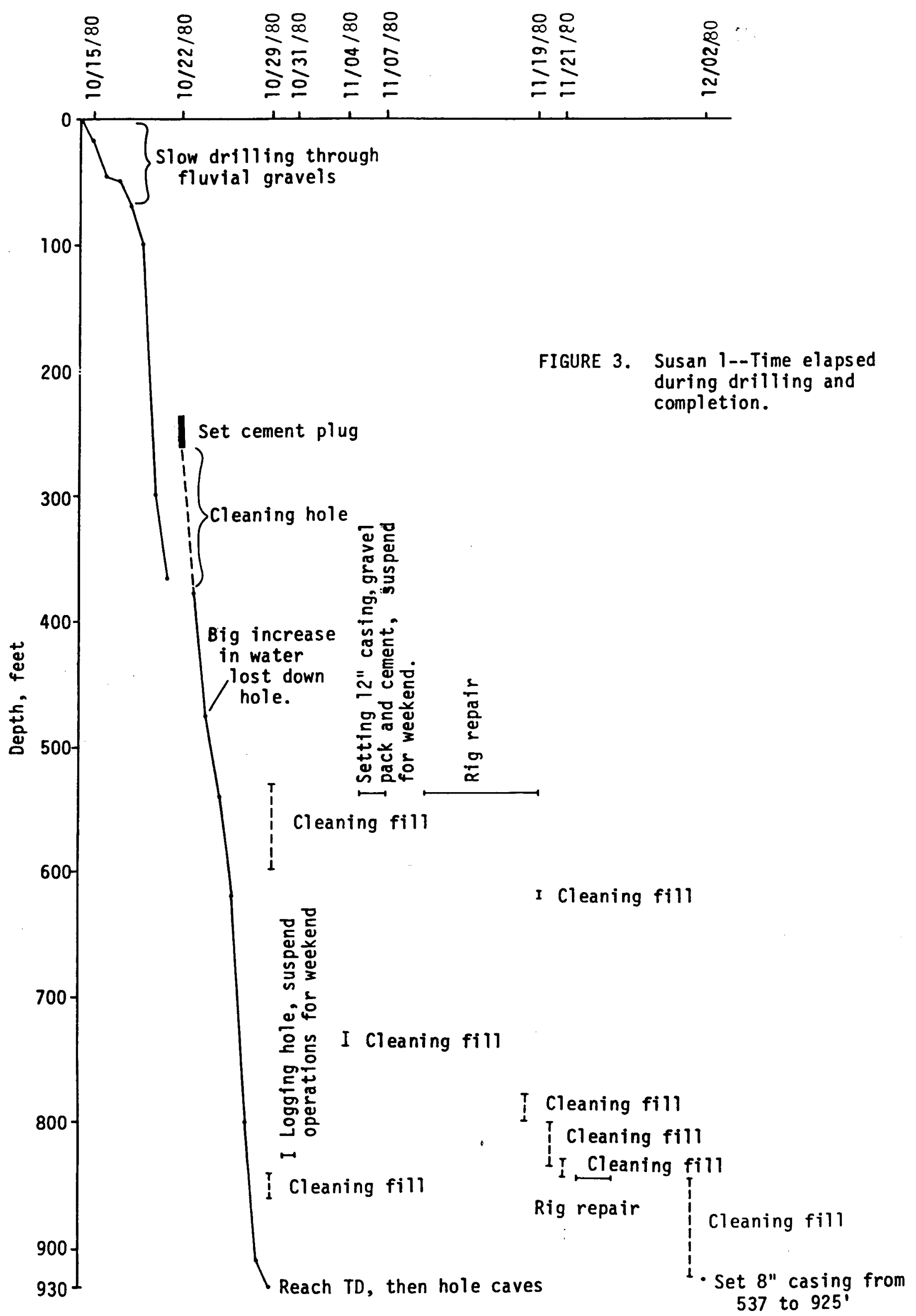

GeothermEx, Inc., 1981 
FIGURE 4. Susan 1 -- Final well dimensions.
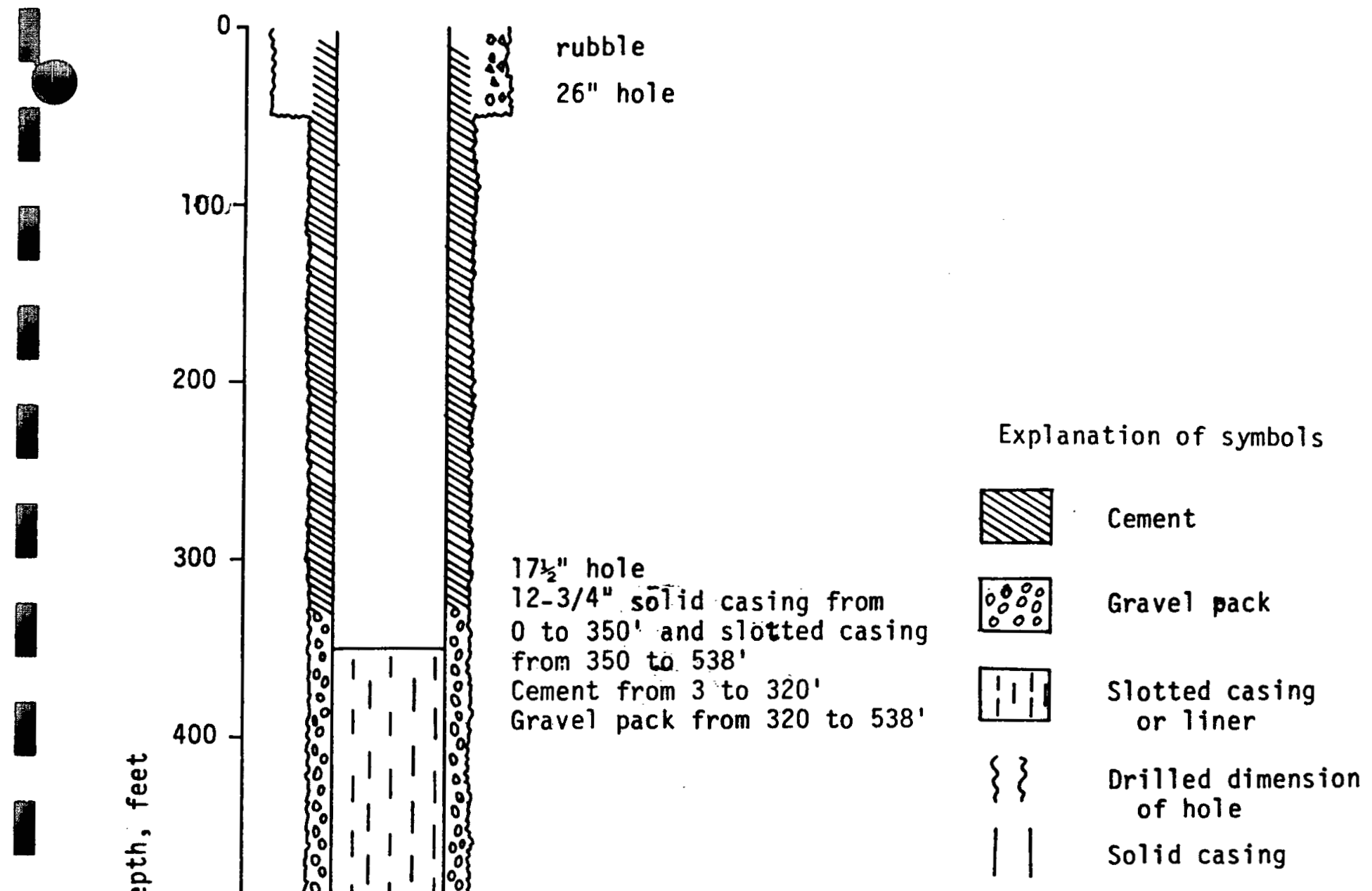

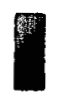

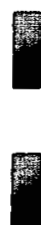

(

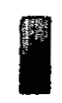

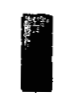

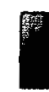

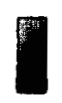

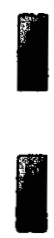

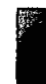

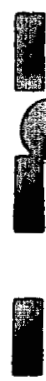

500

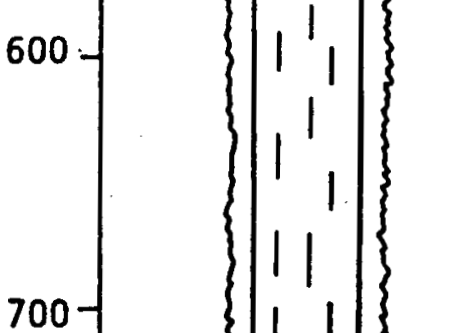

$12 \frac{1}{2} "$ hole to $927^{\prime}$

$85 / 8$ " slotted casing from

520 to $925^{\prime}$ : 
shown on Plate 1 , but the total-loss zone which developed at this depth absorbed the entire capacity of the pump bringing drilling water from the Susan River. Over the next 6 days, more than 275,000 gallons of cold river water were lost down the hole. Unfortunately, data are not available to determine how much of this water moved through the permeable river gravels at the top of the hole, and how much entered deeper permeable zones.

The hole was drilled ahead to 930 feet on October 29 even though large water losses continued almost continuousiy (data regarding water loss and gain are discussed in another section). However, at this depth several things occurred nearly simultaneously:

(1) fine-grained altered volcanics at the bottom of the hole clogged the circulation loop, preventing further drilling and also producing some caving at the bottom of the hole;

(2) coarse fluvial gravels began to cave from the top of the hole; and

(3) fine-grained altered volcanics accumulated in the hole from 530 to approximately 600 feet; these may have caved below the cement plug at 235-260 feet (or that plug may not have completely covered the unstable interval).

The hole was cleaned easily through the zone 530-600 feet. Both volcanic rocks and sloughed alluvium were cleaned below 800 feet; however, the latter zone did not stabilize. The drilling rods were pulled and the hole was left overnight (October 29-30) while water was injected continuously. On October 30-31, various logs were run. More fill gradually accumulated during this time, filling the bottom of the hole from 820 up to 800 feet.

The hole was left during 0ctober 31-November 3 without additional water being injected. On November 4 , small to moderate amounts of fill (altered fine-grained volcanics) were cleaned in several intervals, including 730-740 feet; but overall the hole above 800 feet was in good condition.

On November 5, a combined string of solid and slotted 12-3/4inch casing was run to 538 feet, in order to protect the hole from additional caving at shallow levels and to complete and protect production zones in the interval from 350-540 feet. The interval to be completed with slotted liner had been selected by the authors of this report from interpretation of cuttings, temperature and geophysical logs. 
On November 6 , the annulus between slotted liner and hole wall was grave1-packed from 538-320 feet. It had been intended to stop the gravel at 350 feet, but additional gravel was added accidentally. The gravel behind the solid casing is not expected to affect well performance. On November 7 , cement was pumped into the annulus from 320 feet, with returns visible at about 4 feet below ground level (bottom of "porthole"). After the casing and cement were in place and there was no danger from additional caving in the fluvial section, the 26-inch conductor pipe was pulled.

Cleaning below the 12-3/4-inch casing was carried out from November 11-December 1, with delays caused by rig repair, difficulty in obtaining supplies, and holidays. The level of fill at the bottom of the hole had stabilized at about 800 feet, with a large part being gravel slough from the top of the hole.

Finally, on December 2, 8-5/8-inch slotted casing was run in the interval 520-925 feet, with the casing landed on bottom. The lower casing string was not gravel packed, and the lap (520-538 feet) between the two casing strings was not cemented. 
LOGGING

Drilling Logs

Penetration Rate

Average drilling rates are shown on Plate 1 . These values were calculated from the driller's time records of footage, with allowances made for interruptions to drilling. Drilling rates greater than 20 feet per hour show good correlation with lithology; slower drilling rates are more common.

Water Loss and Gain

Circulation water was lost to permeable zones throughout the drilling period. The variation of the rate of water loss with depth is shown on Plate 1 . These rates are calculated from the data contained in Appendix $A$ and are only approximate because individual values represent losses averaged over a period of several hours, during which time the hole was deepened several tens of feet. Nevertheless, consistent results were obtained, showing a gradual loss ranging from 0.2 to 20 gallons per minute (gpm) up to 450 feet, and then rapidly increasing through the 450-475-foot interval. Because the maximum capacity of the water delivery pump was about $80 \mathrm{gpm}$, no additional data could be obtained below 475 feet.

Susan 1 was observed to produce water briefly on two occasions (Appendix A) before the 12-3/4-inch casing was run. On both of these occasions, the hole was open below 800 feet.

After the 12-3/4-inch casing was run (isolating permeable surficial gravels from the open section at the bottom of the hole), the hole produced water through the casing-drill pipe annulus while circulating at 700-830 feet. On the morning of November 21 , the hole flowed spontaneously at a temperature of $138^{\circ} \mathrm{F}\left(58^{\circ} \mathrm{C}\right)$. Circulation history in the hole before this spontaneous flow was established is as follows: the hole had been cleaned once to 835 feet on the previous afternoon but had caved again to 820 feet during the night. The hole continued to flow with a small head until the porthole in the surface casing was closed on December 6 . This porthole and the connecting horizontal pipe were about 4 feet below ground level. Static water level stabilized at 23 inches below ground level, this being sufficient to balance the head in the permeable strata communicating with the borehole. 
During the time that Susan 1 flowed spontaneously, the temperature rose from $138^{\circ} \mathrm{F}$ to $164^{\circ} \mathrm{F}$ (on November 23), and an odorless gas (believed to be $\mathrm{CO}_{2}$ ) evolved from the water. Temperature dropped slightly to $162^{\circ} \mathrm{F}$ on November 25 with lower rate of gas evolution, and to $158^{\circ} \mathrm{F}$ on December 1 , with very little accompanying gas. A water sample was taken on November 23 and the resulting analys is is given in Appendix B.

The rate of water flow was estimated at $25 \mathrm{gpm}$ on November 24 and somewhat greater on December 1 and 2 .

Return Temperatures

Temperature of the returning drilling fluid was measured at the exit of the mud-circulation loop by means of a dial-type thermometer set into the flow line. During most of the drilling the inlet mud temperature was $45-50^{\circ} \mathrm{F}$ due to the large volumes of river water being lost downhole.

Circulation return temperatures observed while drilling to 930 feet are plotted on Plate 1 ; they mostly range from $50-66^{\circ} \mathrm{F}$. A sharp increase in return temperature, from $62-72^{\circ} \mathrm{F}$, occurred at 920 feet. This may indicate an inflow of warm water at that depth.

Circulation return temperatures during cleaning-out operations were extremely variable, depending largely on the length of time the hole had been undisturbed. However, on November 10, while cleaning out from 770-800 feet, the flow-line temperature rose from $135-147^{\circ} \mathrm{F}$. This part of the hole had been undisturbed for 20 days.

\section{Formation Logs}

Formation logging of Susan 1 included the examination and description of drill cuttings by the GeothermEx well-site geologist, and the running of caliper, spontaneous potential, resistivity, gamma ray and neutron logs by a subcontractor logging service, Welenco of Bakersfield, California. The order of formation logging and production logging is given in Table 1.

The geophysical logs were run soon after the hole was drilled to total depth, but because of partial caving, the bottom 100 feet of the hole could not be logged. Temperature logs also were run at various times. 
Table 1. Sequence of logs in Susan 1.

October 30

$10: 00 \mathrm{AM}$

$10: 45$ AM

$12: 30 \mathrm{PM}$

$1: 00 \mathrm{PM}$

$2: 00 \mathrm{PM}$

$2: 40 \mathrm{PM}$

October 31

Differential temperature in static

Differential temperature in static hole

Depth reached, feet

825

Electric log (SP, long normal and

815

short normal resistivity)

800

3-arm caliper

805

(gamma ray and neutron)

819

4-arm caliper

800

Spinner $\log$ in static hole hole.

815

9:10 AM Spinner log while water is injected

800

10:00 AM Differential temperature while water

800 is injected 
Well Cuttings

Samples from Susan 1 were collected and labeled by the driller at approximately 5-foot intervals, and some additional samples were taken at intermediate points.

Descriptions of the samples are based on examination of the cuttings by binocular microscope. Detailed descriptions are given in Appendix $C$ and are shown graphically on Plate 1. Some work was done by examination of crushed fragments in oil immersion mounts using a petrographic microscope. This involved a small number of samples and was done to check mineral identifications. Because of the finegrained nature of most of the rocks, additional petrographic examination by thin-section and $X$-ray diffraction studies may prove useful.

The $\log$ of Suzy $9 A$ is comparable with the log of Susan 1, when allowance is made for sloughing in Suzy $9 \mathrm{~A}$.

The top 75 feet of the hole penetrated silt, clay, sand, gravel and boulders of a typical fluvial deposit. The coarse fraction included well-rounded basalt, andesite and rhyolite.

In the sedimentary units identified as lake beds(?), two particle size-fractions predominate: very fine ash or clay matrix, similar in mineralogy to the ash/clay matrix described below, and very fine $(0.1 \mathrm{~mm})$ sand. The ash/clay matrix ranges from cream to dark brown in color, probably reflecting differences in oxidation conditions, and ranges in hardness from soft and sticky to relatively hard. The sand particles appear mainly to be red, orange and black (nonmagnetic) iron oxide, but occasional flakes of biotite also were observed.

These sediments probably were derived from volcanic uplands and perhaps also contain an air-fall ash component, especially in the interval 240-260 feet. Difference in hardness and oxidation observed in these samples may reflect in situ hydrothermal alteration and oxidation.

The most common lithology encountered in Susan 1 is very finegrained, relatively homogeneous volcanic ash or clay. These rocks have a very fine-grained matrix (typically $<0.1 \mathrm{~mm}$ ) and are of variable hardness. In some zones, overall hardness is greater than 5; in other zones, the rocks can easily be rubbed into silt-sized paste. Nowhere in the hole could the mineralogy of the matrix be determined at the highest available magnification by binocular microscope $(30 x)$. No small crystals of plagioclase or other typical volcanic phenocrysts were noted at this magnification. 
Composition of the matrix was checked by petrographic microscope using oil immersion mounts of crushed fragments. At magnifications as great as $400 x$, the matrix remains homogeneous. No pumice shards or other textures typical of volcanic glass were noted in the very small sample volumes examined. The matrix is composed of cloudy brown isotropic glass or low birefringent minerals, probably clay. Very small $(0.02 \mathrm{~mm})$ plagioclase crystals were observed in a few instances.

Several color phases of the altered volcanic ash/clay are present. The most common is soft to very hard gray-green rock, typical in the interval 300-480 feet. A gray-brown, soft, very finegrained, very homogenous phase is nearly ubiquitous through the hole below 240 feet, as can be seen from the lithologic log. However, because of the mechanics of the reverse drilling operation, there is very little likelihood that these small percentages of the gray-brown phase are slough from uphole. Other color variations in the volcanic ash/clay sequence are noted in the lithologic log (Appendix C); these probably are caused mainly by changes in conditions of oxidation during alteration.

It is believed that most of the rocks penetrated by Susan 1 are weakly altered and perhaps silicified (because of their hardness) fine-grained volcanics, termed here tuffs. The original mode of deposition may have been as ash-flow units, mud flows, and/or air-fall volcanic ash.

In general, cuttings descriptions in Susan 1 in the interval 300-700 feet are similar to descriptions published for Suzy 9A (Hollinger and Turner, in Benson et al., 1980). Several cores were taken in the corresponding intervals of Suzy 9A (detailed descriptions are given in Appendix $C$ ). Cores at 390-394.3 feet and 507-511.5 feet correspond moderately well with these intervals in Susan 1, although naturally much more detail is visible in the core. The description of core from 682.5-687 feet, however, is rather dissimilar to cuttings returned in Susan 1. It is possible that the core was taken through a boulder.

The depth interval 700-750 feet contains a larger percentage of soft ash/clay matrix, including the gray-brown phase and white, very soft clay matrix, than do the overlying rocks. Thus, although the overall mineralogy is not markedly different from the overlying tuff(?) units, this segment is more likely to be a sedimentary deposit, perhaps of lacustrine origin. Some andesitic boulders may also be present. 
Very hard, medium-gray aphanitic basaltic andesite or basalt is present in the interval 750-815 feet. Although virtually no phenocrysts are visible in this unit, greater hardness and overall texture serves to distinguish the basaltic andesite from the volcanic ash/clay (tuff?) units. No thin-sections of this rock have been prepared; therefore the compositional name is based only on the color of the rock and should be considered provisional. The texture of the basaltic andesite is very dense, unlike the porous texture of nearby andesite outcrops.

Very thin intervals (2-3 feet) of similar-appearing dark-gray rocks were penetrated at 465 and 482 feet; these are thought to be erratic boulders.

The depth interval 815-895 feet contains rocks composed primarily of the ash/clay matrix; they are lighter in color and more bleached-appearing than in upper parts of the section. Soft graybrown phase ash/clay matrix also is present throughout this interval, as is soft, tan to orange, partially oxidized ash/clay matrix.

Because the lithologies show some variability with depth (see Appendix C) and because they are similar overall to the 700-750 foot interval, this interval also is interpreted to be lacustrine sediments(?). However, because the unit is harder than in the 700750 foot interval, and because the ash/clay matrix fraction resembles that found in the tuffs(?), it is possible that these are bleached and altered tuffs.

Dark gray, dense-textured glassy basalt with small $(0.5-1 \mathrm{~mm})$ plagioclase phenocrysts is found in the interval 895-910 feet. Numerous small fractures within individual chips of the cuttings are partially to completely filled with calcite.

The basalt may be interbedded with ash units, because several phases of the volcanic ash/clay are present in these samples.

Calcite is present in fractures throughout most of Susan 1; major occurrences are noted on Plate 1 . Most of these are $1-5 \mathrm{~mm}$ cleavage rhombs, although pyramidally terminated crystals also are present.

Pyrite is sparsely present in many intervals. Commonly it forms small ( $<0.5 \mathrm{~mm})$ brass-colored cubes.

Bright orange to orange-red iron oxide coloration is present in several intervals (Appendix C); major intervals also are noted on Plate 1. 
The volcanic ash/clay (tuff) unit shows films and patches of a yellow-green alteration mineral, probably epidote, in the interval 600-660 feet. This interval of the hole appears to be relatively impermeable.

Caliper $\underline{\log }$

The caliper log shows two washout zones: 225-270 feet and 705-740 feet. These washouts are within the intervals interpreted to be lake beds(?). Thin zones of hole enlargement at 335, 380, 430 and 475 feet may indicate the presence of fractures.

Spontaneous Potential-Resistivity Log

This $\log$ was run from $60-830$ feet. The following units can be recognized on the resistivity log:

60-75 feet: relatively high resistivity and negative SP

75-300 feet: relatively low resistivity with a resistive interval of low SP peaks

300-630 feet: alternating zones of relatively high to moderate resistivity with relatively featureless SP

630-710 feet: moderate resistivity, but featureless SP

710-740 feet: relatively low resistivity, featureless SP

740-810 feet: highly variable resistivity, featureless SP

810-830 feet: low resistivity, featureless SP

The poor SP response reflects the lack of resistivity contrast between the formation fluid and drilling fluid and the presence of a clayey matrix. In general, high resistivity denoted basalts and andesites, and low resistivity denoted clay, ash and tuff.

Gamma Ray-Neutron Log

This $\log$ was run from $60-810$ feet. The gamma ray $\log$ is relatively featureless (except for background noise), reflecting the relatively uniform chemical composition of the dominantly volcanic 
section. The gamma ray log from Suzy 9A (Benson et al., 1980), however, displays relatively low values in the upper 300 feet of hole.

The neutron log shows very low counts (high hydrogen content in the rocks of the logged interval) down to 250 feet; a gradual build-up in the 250-300 foot interval, and variably moderate to high counts below 300 feet.

\section{Production Logs}

Two types of production logs were run: temperature and spinner. Temperature logs were run by Welenco with continuous recording equipment and by GeothermEx with dial-indicator equipment. The spinner logs were run by Welenco.

Temperature Logs

Non-equilibrium (injecting) and partial temperature recovery logs of Susan 1 are given in Plate 2 and Figures 5 and 6 . Those taken before November 1 are in the uncased hole, while later logs are in partially cased hole.

Equilibrium temperature logs of Suzy $9 A$ are available from October 1979 (taken in 2-inch water-filled pipe 3 months after drilling); non-equilibrium (flowing) logs and partial temperature recovery logs of Suzy 9A were taken in October and November 1980 (Plate 2 and Figure 5). The configuration of Suzy 9A during the latter logging consisted of 8-inch blank casing from 0-78 feet, 4-inch blank steel pipe from 2 feet above ground level to 333 feet depth, cemented at the surface to the 8-inch casing, and open hole (drilled at 6-1/2-inch diameter) from 313-818 feet. The 2-inch gradient pipe had been pulled and the 4-inch pipe had been installed in preparation for flow tests during January 1980.

The temperature logs run in Suzy $9 \mathrm{~A}$ during the drilling of Susan 1 were particularly helpful in determining the location of permeable zones and consequently in determining the proper depth for setting blank and slotted casings.

On October 24, when Susan 1 was 413 feet deep, water began to flow from the 4-inch pipe in Suzy $9 A$ and from leaks in the cement between the 4-inch and 8 -inch pipes. This water initially was at $71^{\circ} \mathrm{F}$, but rose to $80^{\circ} \mathrm{F}$ within 8 hours. Suzy $9 \mathrm{~A}$ continued to flow through 


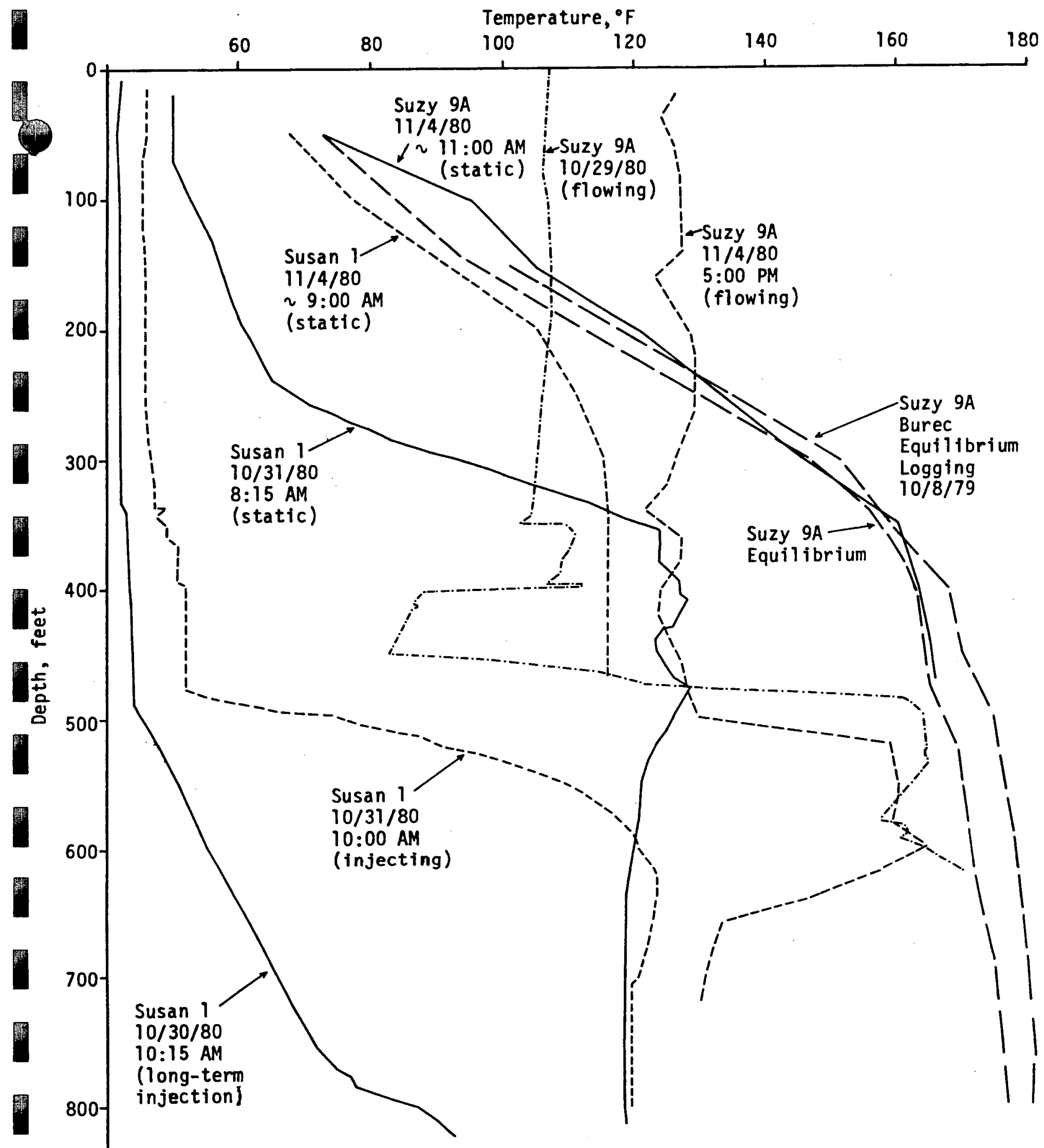

900

FIGURE 5. Temperature logs of Susan 1 and Suzy 9A, 10/8/79 through $11 / 4 / 80$. 


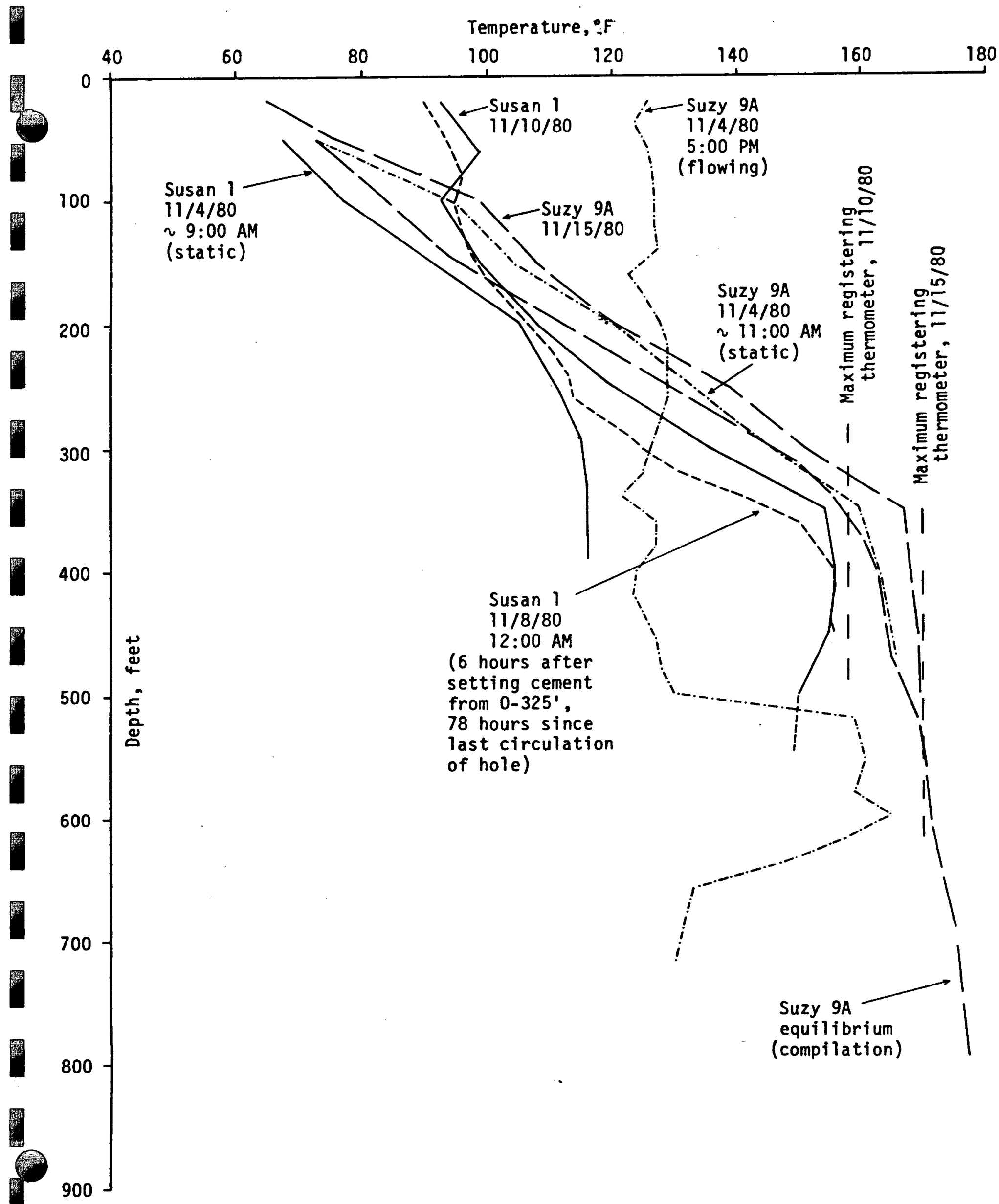

FIGURE 6. Temperature logs of Susan 1 and Suzy 9A, 11/4/80 through $11 / 15 / 80$. 
November 25 in response to changes in head in Susan 1 long after the top 350 feet of Susan 1 had been hydrologically isolated by casing and cement. On many occasions, Suzy 9A would begin to flow when circulation in Susan 1 was turned off, but flow from Suzy 9A would cease within 2-3 minutes of the resumption of circulation. However, the water flowing from Suzy $9 \mathrm{~A}$ was always much warmer than the water being circulated in Susan 1, with the highest observed outflow temperature being $127^{\circ} \mathrm{F}$ on October 31 .

Logs of Suzy $9 A$

Temperature logs of Suzy $9 A$ not only demonstrated that there are several permeable zones below 350 feet, but in addition, equilibrium logs from Suzy 9A taken in 1979 provide the best data presently available on deep temperatures at this site, because no equilibrium temperature data are available below about 400 feet in Susan 1.

The most detailed and informative log from Suzy $9 A$ was run under flowing conditions on October 29 by Welenco. This log shows sharp changes in temperature below 350 feet, which undoubtedly are caused by water moving in permeable zones. However, it is not known how many zones of entry contributed to the surface flow of $107^{\circ} \mathrm{F}$ (flow rate estimated at $25 \mathrm{gpm}$ ). The flow could represent about $85 \%$ water at $110^{\circ} \mathrm{F}$ mixed with about $15 \%$ water at $88^{\circ} \mathrm{F}$. However, other proportions of mixing could produce the observed outflow temperatures.

Logs of Susan 1

Three detailed temperature logs were run in Susan 1 by Welenco as part of the suite of geophysical logs; they are shown on Figure 5 and are given on Plate 2 for ease in comparison with the other types of logs. The temperature logs were made under different injection conditions and give important data concerning down-hole permeability.

Later, logs were run to partial depth in Susan 1; they are shown in Figure 6.

The first $\log (10: 15 \mathrm{AM}, 10 / 30 / 80)$ was run immediately after stopping injection; it shows that the hole was thoroughly chilled as a result of long-term injection of cold water. Cold water entered fractures or other permeable zones in the interval 100-490 feet to keep the hole nearly isothermal at $42-44^{\circ} \mathrm{F}$. 
From 490-755 feet, the profile is a nearly straight-1ine gradient at $8.9^{\circ} \mathrm{F} / 100$ feet. This smooth profile results from lower permeability in the hole below 490 feet.

A small bump on the profile at $775-785$ feet and also the sharp increase in temperature from 790-825 feet indicates even less permeability in this zone as compared with the $490-775$ foot interval.

The second $\log (8: 15 \mathrm{AM}, 10 / 31 / 80)$ was taken 22 hours after injection ceased, and the temperature increase throughout the hole is dramatic. In the interval $335-475$ feet the temperature rose some $80^{\circ} \mathrm{F}$ from the previous log; and the jagged nature of the profile clearly indicates warm water flowing into the hole. The temperature reversal from 475-640 feet and the nearly isothermal profile from 640-814 feet probably indicates little water inflow, with temperature recovery controlled by conductive heat transfer; but even here the temperature increased a minimum of $50^{\circ} \mathrm{F}$.

The third $\log (10: 00 \mathrm{AM}, 10 / 31 / 80)$ shows that permeable zones in the interval 335-475 feet are invaded by cold water, because they have been chilled to $52^{\circ} \mathrm{F}$ after less than 2 hours injecting. The lower part of the hole is less affected, with the interval 705-800 feet still isothermal and slightly warmer than during the second logging. The part of the profile from 600-800 feet is somewhat warmer during the third logging run than during the second.

Comparison of these three logs with equilibrium temperature profiles of Suzy $9 A$ shows that the hydrologic and thermal response of Susan 1 is rapid. This is confirmed by the fact that $174^{\circ} \mathrm{F}$ water was pumped from the initial flow tests on December $4-5,1980$.

Figure 6 shows temperature logs of Suzy $9 A$ and Susan 1 taken before the latter had been completely cleaned out and cased to total depth. These logs were measured by GeothermEx using several different instruments, which could reach various depths before becoming stopped by irregularities in the hole.

They show that equilibrium temperatures below 300 feet in both Susan 1 and Suzy $9 \mathrm{~A}$ are consistently higher than $150^{\circ} \mathrm{F}$ under static conditions; but that the water flowing from Suzy $9 \mathrm{~A}$, at about $120^{\circ} \mathrm{F}$, is a mix of hot and cold components. This is in contrast to the flowing temperature of Susan 1, which ranges between $150^{\circ}$ and $175^{\circ} \mathrm{F}$, depending on duration of flow. Clearly, this difference in flowing temperature between the two wells is due to the mixing of drilling fluid in the outflow of Suzy $9 \mathrm{~A}$. 
The static temperature logs taken on November 4, 1980 represent about 100 hours since last circulation of water in the hole. The $\log$ on November 10 represents about 135 hours since last circulation, and the $\log$ on November 15 represents about 60 hours since last disturbance of Suzy $9 A$.

It should also be noted that in a chemical analysis of water sampled on November 23, 1980 from Susan $1, \mathrm{SiO}_{2}$ was reported at 82.6 $\mathrm{mg} / \mathrm{l}$ (Appendix B). This corresponds to a chalcedony solubility temperature of almost $208^{\circ} \mathrm{F}$, and to a conductive quartz temperature of $260^{\circ} \mathrm{F}$. It is reasonable to assume that temperatures approaching $200^{\circ} \mathrm{F}$, or even significantly higher, are to be found within the thermal aquifer supplying Susan 1 . The observed $174^{\circ} \mathrm{F}$ flow temperature and the equilibrium value of $180^{\circ} \mathrm{F}$ for Suzy $9 \mathrm{~A}$ are taken as minimum equilibrim values for Susan 1 .

\section{Spinner Log}

Four spinner logs were run by Welenco; one up-run and one station run under static (shut in) conditions; and one up-run and one down-run under injection conditions.

Although there is considerable noise on the traversing $\log$ taken under static conditions, neither this log nor the station log shows evidence for fluid movement within the hole under shut-in conditions.

The up-run taken under injection conditions gave no interpretable results, probably because the tool velocity was too high ( 50 $\mathrm{ft} / \mathrm{min}$ ) in comparison with fluid velocities: that is, the differential velocity was too small to be detected. Larger injection rates or slower tool speeds would be needed in order to obtain interpretable results.

The down-run also gave very noisy results, but because both the fluid and the tool were moving in the same direction, the differential velocity was smaller than in the up-run, and a tentative interpretation can be made. If it is assumed that the tool had a higher velocity than the fluid over the entire depth of the hole, it appears that most of the injected fluid leaves the hole before reaching the depth of 375 feet; all of it appears to leave before reaching 500 feet. 


\author{
STRATIGRAPHIC SEQUENCE AND \\ RESERVOIR CHARACTERISTICS \\ AS INTERPRETED FROM WELL LOGS
}

\title{
Stratigraphic Sequence
}

The alluvial section at the top of the hole is identified to extend from 0-75 feet, on the basis of :

(1) Cuttings log.

(2) Drilling rate.

(3) Caliper log.

(4) Resistivity log, where there is a sharp decrease in resistivity at the base of the unit.

Lake beds(?) are interpreted to occupy the interval 75-280 feet, with the bottom boundary based primarily on the caliper and cuttings log. Factors that contributed to this interpretation are:

(1) Cuttings log, with mixed fine-grained, apparently clay-rich components within the interval, including homogeneous units of possibly water-laid or air-fall ash at 235-260 feet.

2) Caliper log showing large wash-outs, corresponding to the softest zones.

(3) Resistivity log showing very low resistivity, indicating a high clay content.

(4) Neutron log indicating a high water content.

Tuffs(?) are interpreted to occupy the interval 280-700 feet. This name is applied on the basis of:

(1) The cuttings log, which shows the rocks to be relatively homogeneous very fine-grained altered volcanic ash/clay.

(2) The caliper log showing relatively competent rock, with a few possible fractures.

(3) Regular variations in the resistivity log, which may indicate large-scale differences in bedding, welding, or alteration.

(4) The neutron log showing relatively low water content. 
Lake beds(?) are interpreted in the interval 700-750 feet, based mainly on:

(1) Caliper $\log$ and drilling rates indicating the degree of softness.

(2) Neutron $\log$ showing high water content.

(3) Cuttings log showing a high concentration of possible airfall or water-laid ash.

The basaltic andesite interval from 750-815 feet is identified chiefly from:

(1) Cuttings log.

(2) Relatively hard rocks, shown by drilling rate and caliper logs.

(3) Resistivity log showing relatively high, variable resistivity.

Lake beds(?) in the interval 815-895 and 915-930 feet are interpreted on the basis of similarity of cuttings with the 700-750 foot interval. Geophysical logs do not extend below 815 feet because the bottom of the hole was filled with slough.

The basalt interval from $895-915$ feet is identified from:

(1) Cuttings log.

(2) Drilling rate and caliper logs indicating relatively hard rocks.

Nature and Thickness of Permeable Zones

The permeable zones in Susan 1 have been identified from temperature logs of Susan 1 and Suzy 9A; and from the spinner log. It should be noted that neither temperature logs nor geophysical logs are available below 825 feet in either hole, but circulation return temperatures gave a sharp increase at 920 feet in Susan 1. If permeable zones exist below 825 feet ( 1 imit of temperature $10 \mathrm{~g}$ ) in Susan 1, they should contribute to total flow through the 8-5/8-inch slotted casing. 
Permeable zones in the interval $350-460$ feet in Susan 1 constitute the aquifer. Three zones at 350, 400 and 460 feet have especially high permeability. These three zones clearly are visible on the 23-hour build-up temperature $\log$ (Figure 5; 8:15 AM, 10/31/80).

The aquifer occurs within the stratigraphic interval identified as tuff(?); no particular differences in component grain size, hardness or mineralogy are noted in the very permeable zones and surrounding samples.

Available cuttings did not permit the identification of bedding planes, rubble zones, zones of partial welding or other stratigraphically controlled intervals of higher or lower permeability in the tuff(?) unit. If sandy or pebbly interbeds occur in the tuff(?) unit, they were not identified in the cuttings.

Fractures may contribute to permeability in the aquifer. Numerous hairline fractures, which were partially to completely filled with calcite, were observed in cuttings in the tuff(?), as well as elsewhere in the hole.

Several cores were taken in Suzy $9 A$ in the unit identified here as tuff(?). That from 390-394.3 feet showed no natural fractures; that from 507-511.5 feet showed fractures, most of which were healed with calcite, and that from 682.5-687 feet showed fractures and voids which are reported to be healed or partially filled with calcite, possibly representing two events of secondary mineralization (Hollinger and Turner, in Benson et al., 1980).

These data show that despite variable degrees of hardness, the tuff(?) units are sufficiently brittle to fracture. However, the present-day permeability of the fractures is not known; nor is it known whether they contribute significantly to production in the aquifer. 
A preliminary, short-term pump test of Susan 1 was conducted on December $4-6,1980$. The hole was pumped at various rates ranging from 150-700 gpm. Appendix D gives data from this test. The largest period of pumping was 6 hours at $350 \mathrm{gpm}$. For the $150 \mathrm{gpm}$ rate, the flow measurement was deemed wrong; and for the $700 \mathrm{gpm}$ rate, the duration of flow was too short to have achieved a stabilized drawdown. Figure 7 is a deliverability plot for Susan 1 based on flow rate versus observed drawdown, excluding the 150 and $700 \mathrm{gpm}$ cases. Although there are only 3 reliable points to the line, Figure 7 can be used to estimate the expected drawdown at any given flow rate.

From the pump test, the drawdown data at both 250 and $350 \mathrm{gpm}$ were analyzed by standard semilog plotting (Figure 8) as well as by type-curve matching, to yield values of permeability-thickness product $(\mathrm{kh})$, storativity $(\phi \mathrm{ch})$ of the aquifer, and the skin factor. The build-up data at both 250 and $350 \mathrm{gpm}$ were analyzed by Horner plot (Figures 9 and 10 ) to calculate $k h$ and the skin factor. Table 2 presents the results.

The difference between the $k h$ values calculated by various methods (Table 2) is due to the short-term nature of the flow test, with its inherently limited interpretative approaches. This pump test has obtained a valid approximation of the well's capability; the formation characteristics should be calculated from a long-term interference test to be conducted in the near future.

The calculated range of $\mathrm{kh}$ values of $1.10-2.01 \times 10^{6} \mathrm{md} \cdot \mathrm{ft} /$ psi compares well with the range of $0.43-3.6 \mathrm{md} \cdot \mathrm{ft} / \mathrm{ps} \mathrm{i}$ reported by $\mathrm{LBL}$ (1979) from interference tests on several wells in the southern part of the City of Susanville. The range of storativity values $(2.45-3.06$ $x 10^{-5} \mathrm{ft} / \mathrm{psi}$ ) in Table 2 is much less than the range of 23-72 $x$ $10^{-5} \mathrm{ft} / \mathrm{psi}$ reported by LBL (1979). This difference may arise because: (1) wells tested by $L B L$ are in the southern part of the city, where sediments are more sandy and hence have higher storativity; (2) the net permeable zone in Susan 2 is less than in wells in the south, for wells Suzy $9,9 A$ and 11 in the northern part of the city show very few permeable zones.

The deliverability of geothermal well Susan 1 is of the same order as the other thermal wells in the city because their kh values are similar. For example, U. S. Bureau of Reclamation (1976) reported a "transmissivity" of 16,000 $\mathrm{gpd} / \mathrm{ft}$ from a well in the southern edge of the city (North State Growers' well). This value of deliverability 


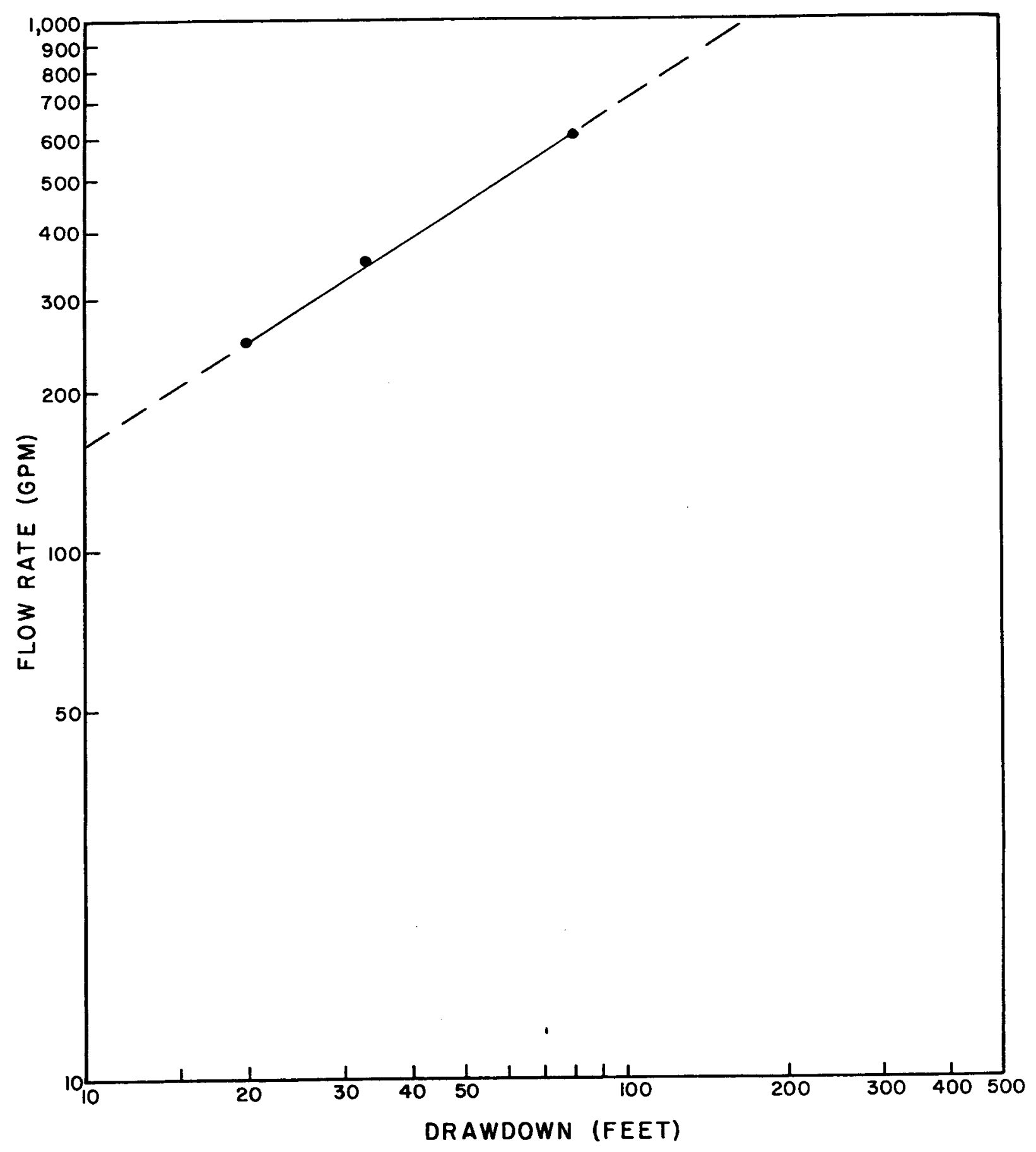

FIGURE 7 . Deliverability of Susan 1. 


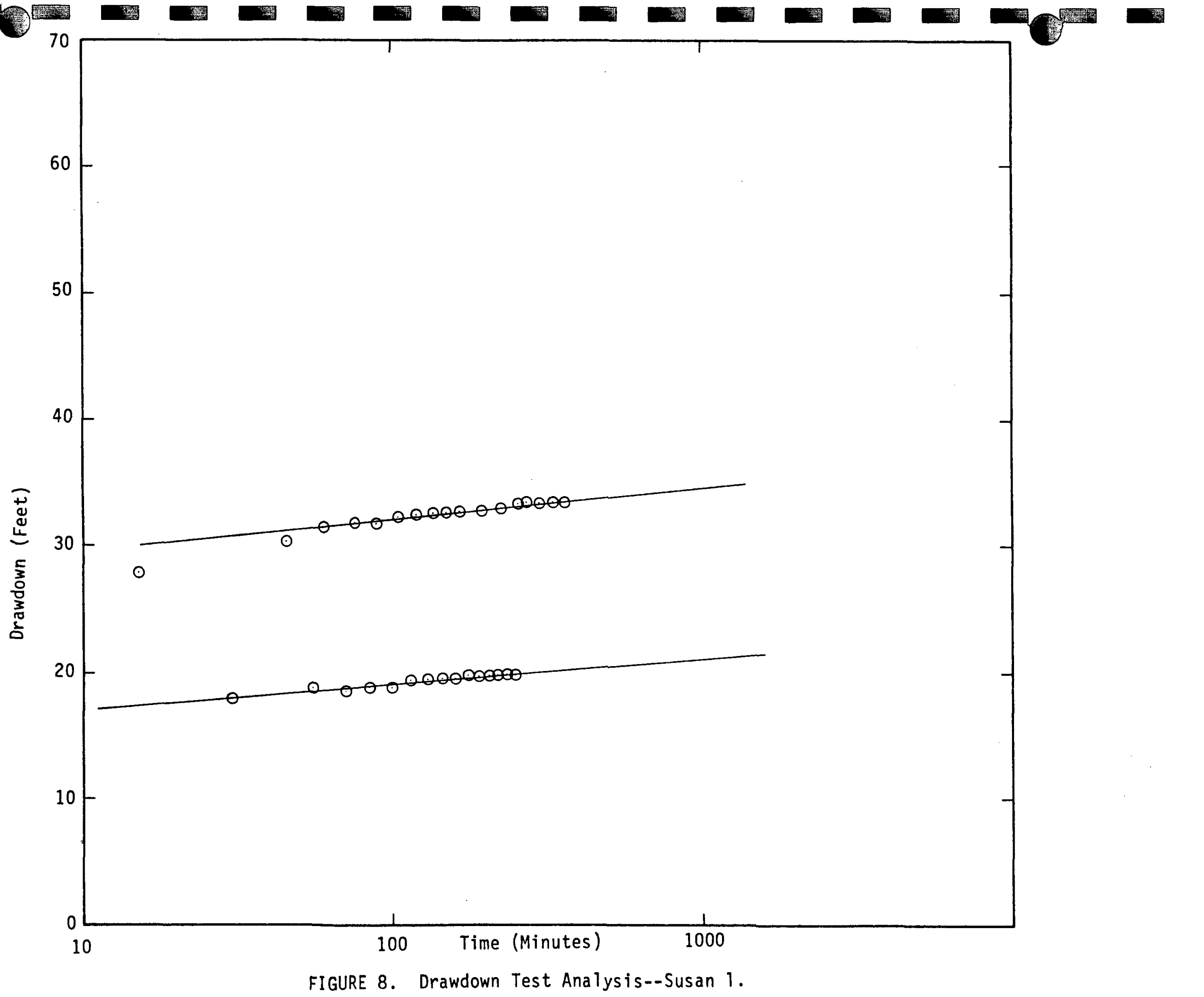




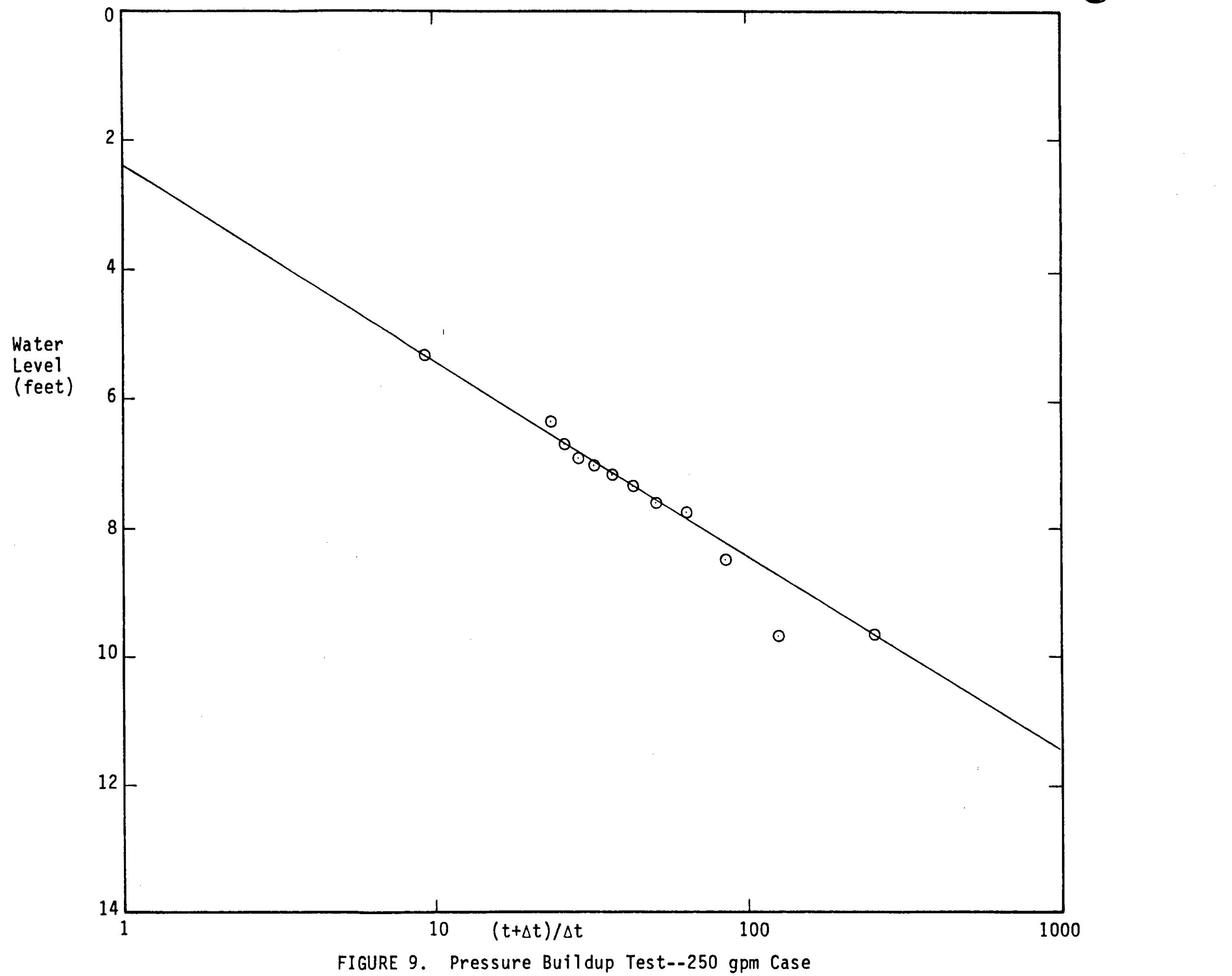




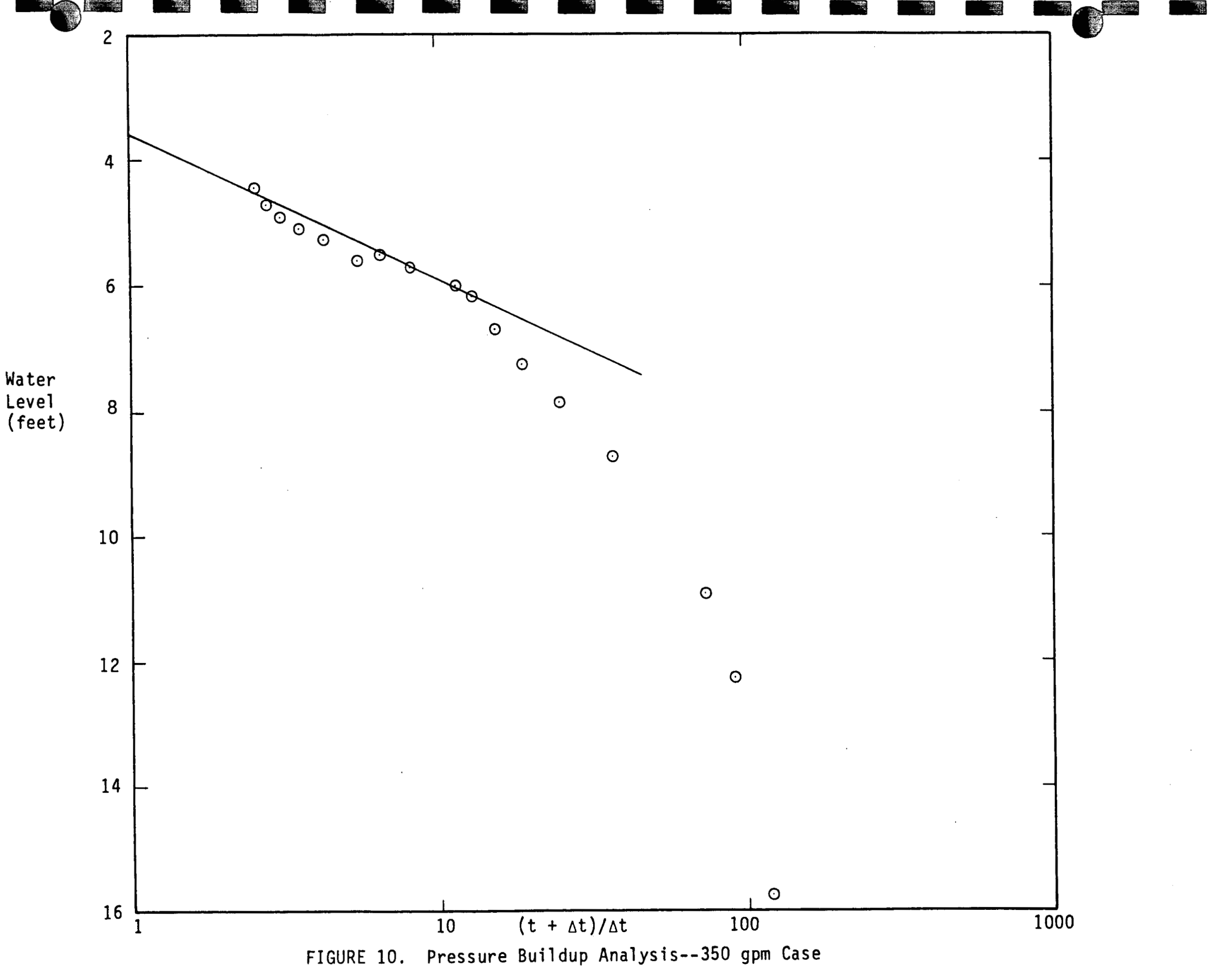


Table 2. Results of Preliminary Pump Test of Susan 1

\section{Analysis Basis}

1. Drawdown during production at $250 \mathrm{gpm}$
a. Semi-log plot
b. Type-curve matching
$2.45 \times 10^{-5}$
$1.66 \times 10^{6}$
2.0
$1.33 \times 10^{6}$

2. Build-up after production at $250 \mathrm{gpm}$

Storativity,
$\phi c h(f t / p s i)$

Transmissivity, $\mathrm{kh} / \mu$ (md.ft/cp)

Sk in

Factor, $S$

3. Drawdown during production at $350 \mathrm{gpm}$
a. Semi-log plot
$\times 10^{-5}$
$1.85 \times 10^{6}$
5.8
b. Type-curve matching
$3.06 \times 10^{-5}$
$1.11 \times 10^{6}$

4. Build-up after production at $350 \mathrm{gpm}$

$2.01 \times 10^{6}$

6.0 
equals $11.1 \mathrm{gpm} / \mathrm{ft}$ of drawdown. By comparison, from Figure 7 we find that for a $250 \mathrm{gpm}$ flow the drawdown is $19.8 \mathrm{ft}$, giving a deliverability of $12.6 \mathrm{gpm} / \mathrm{ft}$. Figure 7 also shows that at $350 \mathrm{gpm}$ the deliverability is $10.5 \mathrm{gpm} / \mathrm{ft}$. Thus, the deliverability of Susan 1 compares favorably with that reported by U. S. Bureau of Reclamation (1976). 


\section{CONTINUED TESTING}

As stated above, it will be necessary to perform longer-term tests (1) to confirm the initial observations and calculations, and (2) to develop a quantitative reservoir model for continued developmental forecasts. Stages of testing should be as follows.

1. A carefully designed interference test should be run on Susan 1 , using a number of strategically selected wells in other parts of the city as monitor wells. The exact location and number can be determined later this year. Test duration should be a minimum of 30 days. Flow rates would be estab1 ished in Susan 1, and drawdown monitored both in Susan 1 and the selected monitor wells.

2. Simultaneously, there should be a detailed correlation of geological, geophysical and drilling data from all thermal wells in the City of Susanville, leading to the establishment of a geological model of the thermal reservoir. This would involve construction of subsurface structure maps and crosssections and calculation of volumes of sediment available to serve as thermal aquifers. Faults and 3-dimensional circulation patterns would be described.

3. Based on the geological model and the interference test data, a quantitative reservoir model should be developed. This reservoir model will be used to assess reservoir capacity and to forecast long-term well performance.

4. From this, it can be decided whether and where to drill a second production well and/or an injection well for wastewater disposal. Various operational constraints must be considered, including land availability, and the need for a revised drilling, casing and completion program to satisfy anticipated conditions of caving formations. 


\section{NOMENCLATURE}

$\begin{aligned} & c= \text { Effective compressibility of the reservoir } \\ & \text { rock/fluid systems, psi-1 }\end{aligned}$

$h=$ Net reservoir thickness, feet

$k=$ Permeability, millidarcy

$S=$ Skin Factor, dimensionless

$\phi=$ Porosity, fraction

$\mu=$ Fluid viscosity, centipoise 


\title{
REFERENCES
}

\author{
Benson, S., Goranson, C., Noble, J., Schroeder, R., Corrigan, D., \\ and Wollenberg, H., 1980, Evaluation of the Susanville, \\ California geothermal resource: Lawrence Berkeley Laboratory, \\ LBL-11187, $100 \mathrm{p}$. \\ LBL, 1979, Investigations at the Susanville KGRA-1978-1979: USBR \\ Contract No. 14-06-200-8612A. \\ U. S. Bureau of Reclamation, 1976, Water quality analysis, inferred \\ geothermal reservoir temperature, and reservoir evaluation \\ test: Interagency Agreement No. E (04-3)-1292.
}




\section{APPENDIX A}

Summary of Water Loss and Gain in Susan 1 


\section{Appendix A}

Summary of Water Loss and Gain in Susan 1.

\begin{tabular}{|c|c|c|c|c|c|c|}
\hline Date & $\begin{array}{l}\text { Hole } \\
\text { Depth, } \\
\text { (feet) }\end{array}$ & $\begin{array}{l}\text { Time to begin } \\
\text { adding water to pit } \\
\text { (expressed in } \\
\text { 24-hour clock) } \\
\end{array}$ & $\begin{array}{r}\begin{array}{r}D \\
\text { of } \\
(n\end{array} \\
\text { Timed } \\
\end{array}$ & $\begin{array}{l}\text { ration } \\
\text { Pumping } \\
\text { inutes) } \\
\text { Estimated }\end{array}$ & $\begin{array}{l}\text { Estimated } \\
\text { Water Volume } \\
\text { Added } \\
\text { (hundreds } \\
\text { of gallons) } \\
\end{array}$ & $\begin{array}{l}\text { Calculated } \\
\text { Rate of } \\
\text { Water Loss } \\
\text { (gal/min) } \\
\end{array}$ \\
\hline $10 / 18$ & $\begin{array}{c}50-60 \\
60\end{array}$ & $\begin{array}{c}3 \text { times during night } \\
1030 \\
1335\end{array}$ & $\begin{array}{l}22 \\
11\end{array}$ & 15 & $\begin{array}{r}12 \\
18 \\
9\end{array}$ & .15 \\
\hline $10 / 19$ & -- & ? & & & & \\
\hline $10 / 20$ & $\begin{array}{l}123 \\
225 \\
275\end{array}$ & $\begin{array}{l}1150 \\
1800 \\
2045\end{array}$ & 11 & $\begin{array}{l}5 \\
5\end{array}$ & $\begin{array}{l}9 \\
4 \\
4\end{array}$ & 3.17 \\
\hline $10 / 21$ & $\begin{array}{l}315 \\
330 \\
345 \\
350 \\
360\end{array}$ & $\begin{array}{l}0045 \\
0315 \\
0600 \\
0700 \\
1113\end{array}$ & 12 & $\begin{array}{l}5 \\
5 \\
5 \\
5\end{array}$ & $\begin{array}{r}4 \\
4 \\
4 \\
4 \\
10\end{array}$ & 3.8 \\
\hline $10 / 22$ & --- & & & & & \\
\hline \multirow[t]{3}{*}{$10 / 23$} & cleaning & 1700 & & 5 & 4 & \\
\hline & from $240-$ & 1930 & & 5 & 4 & \\
\hline & 375 & $\begin{array}{l}2055 \\
2140 \\
2330\end{array}$ & $\begin{array}{r}10 \\
3\end{array}$ & 5 & $\begin{array}{l}8 \\
2 \\
4\end{array}$ & 5.6 \\
\hline $10 / 24$ & $\begin{array}{l}382 \\
383 \\
388\end{array}$ & $\begin{array}{l}0024 \\
0100 \\
0151\end{array}$ & $\begin{array}{r}6 \\
10 \\
5\end{array}$ & & $\begin{array}{l}5 \\
8 \\
4\end{array}$ & 19.5 \\
\hline & $\begin{array}{l}390-400 \\
400-410 \\
410-420 \\
420-430 \\
430-440 \\
440-450 \\
450-460 \\
460-470 \\
480\end{array}$ & $\begin{array}{l}0230-0445 \text { ( } 4 \text { times) } \\
0545-0645 \text { (3 times) } \\
0740-0900 \text { (3 times) } \\
0930-1035 \text { (3 times) } \\
1120-1305 \text { (3 times) } \\
1400-1500 \text { (2 times) } \\
1523-1609 \text { (2 times) } \\
1630-1730 \text { (2 times) } \\
1845 \text { (cont inuous) }\end{array}$ & $\begin{array}{l}10 \\
17 \\
33\end{array}$ & $\begin{array}{r}20 \\
15 \\
15 \\
15 \\
15 \\
5\end{array}$ & $\begin{array}{l}16 \\
12 \\
12 \\
12 \\
12 \\
12 \\
14 \\
26 \\
96\end{array}$ & $\begin{array}{l}21.3 \\
20.0 \\
15.0 \\
18.5 \\
11.4 \\
20.0 \\
30.4 \\
43.3 \\
80.0\end{array}$ \\
\hline & $\begin{array}{l}\text { Note: Ver } \\
\text { tion sucke } \\
\text { tion. }\end{array}$ & $\begin{array}{l}\text { large loss of circu } \\
\text { pit dry during conn }\end{array}$ & & & & \\
\hline
\end{tabular}


Appendix A (cont inued)

\begin{tabular}{|c|c|c|c|c|c|c|}
\hline \multirow[t]{2}{*}{ Date } & $\begin{array}{l}\text { Hole } \\
\text { Depth, } \\
\text { (feet) }\end{array}$ & $\begin{array}{l}\text { Time to begin } \\
\text { adding water to pit } \\
\text { (expressed in } \\
\text { 24-hour clock) }\end{array}$ & \multicolumn{2}{|c|}{$\begin{array}{l}\text { Duration } \\
\text { of Pumping } \\
\text { (minutes) }\end{array}$} & $\begin{array}{l}\text { Est imated } \\
\text { Water Volume } \\
\text { Added } \\
\text { (hundreds } \\
\text { of gallons) }\end{array}$ & $\begin{array}{l}\text { Calculated } \\
\text { Rate of } \\
\text { Water Loss } \\
\text { (gal/min) } \\
\end{array}$ \\
\hline & 480 & $\begin{array}{l}2155 \\
1135\end{array}$ & & $\begin{array}{l}50 \\
15\end{array}$ & $\begin{array}{l}40 \\
12\end{array}$ & \\
\hline $10 / 25$ & $480-530$ & $\begin{array}{l}0010-0813 \text { (11 times) } \\
0955-1630 \text { (continuous) } \\
\text { Note: Pit sucked dry } \\
\text { within } 20 \text { minutes when } \\
\text { water pump interrupted } \\
\text { and circulation stopped. }\end{array}$ & 395 & 165 & $\begin{array}{l}132 \\
316\end{array}$ & \\
\hline & $\begin{array}{l}\text { Pit ref } \\
\text { PM and } \\
\text { corded. }\end{array}$ & $\begin{array}{l}\text { led numerous times on } 10 / \\
\text { ring } 10 / 26 \text {; times not re- }\end{array}$ & & & & \\
\hline $10 / 27$ & $\begin{array}{l}\text { at } 620 \\
630-730 \\
740-750 \\
750-800\end{array}$ & $\begin{array}{l}0005-0700 \text { ( } 7 \text { times) } \\
0710-1530 \text { (cont inuous) } \\
1610-1700 \text { (cont inuous) } \\
0810-1115 \text { (cont inuous) }\end{array}$ & $\begin{array}{r}480 \\
50 \\
180\end{array}$ & 100 & $\begin{array}{r}80 \\
384 \\
40 \\
144\end{array}$ & \\
\hline \multirow[t]{3}{*}{$10 / 28$} & $800-805$ & $0000-0430$ (continuous) & 270 & & 216 & \\
\hline & $\begin{array}{l}\text { Note: } \\
\text { at } 0130 \\
\text { However, } \\
\text { steady, } \\
0400 . \\
\text { pit dry } \\
\text { arily st }\end{array}$ & $\begin{array}{l}\text { ter circulation turned of } \\
\text { n order to trip out of ho } \\
\text { pit volume held relativel } \\
\text { nd even increased at } 0300 \\
\text { contrast, hole had sucke } \\
\text { hen circulation was tempo } \\
\text { pped } 5 \text { hours earlier. }\end{array}$ & & & & \\
\hline & $\begin{array}{c}\text { at } 805 \\
805-810 \\
810-820 \\
830 \\
840 \\
845 \\
850 \\
860 \\
865 \\
880 \\
895 \\
905\end{array}$ & $\begin{array}{c}0630-0910 \text { (3 times) } \\
0930-1025(2 \text { times) } \\
1130 \\
1235 \\
1330 \\
1345 \\
1500 \\
1609 \\
1644 \\
1820 \\
1937 \\
2130\end{array}$ & $\begin{array}{l}85 \\
60 \\
35 \\
15 \\
40 \\
40 \\
20 \\
16 \\
71 \\
45 \\
49 \\
40\end{array}$ & & $\begin{array}{l}68 \\
48 \\
28 \\
12 \\
32 \\
32 \\
16 \\
13 \\
57 \\
36 \\
39 \\
32\end{array}$ & \\
\hline $10 / 29$ & $\begin{array}{l}920 \\
930\end{array}$ & $\begin{array}{l}0000 \\
0200\end{array}$ & $\begin{array}{r}30 \\
150\end{array}$ & & $\begin{array}{r}24 \\
120\end{array}$ & \\
\hline
\end{tabular}


Appendix A (continued)

\begin{tabular}{|c|c|c|c|c|c|}
\hline & $\begin{array}{l}\text { Hole } \\
\text { Depth, }\end{array}$ & $\begin{array}{l}\text { Time to begin } \\
\text { adding water to pit } \\
\text { (expressed in }\end{array}$ & $\begin{array}{c}\text { Duration } \\
\text { of Pumping } \\
\text { (minutes) }\end{array}$ & $\begin{array}{l}\text { Estimated } \\
\text { Water Volume } \\
\text { Added } \\
\text { (hundreds }\end{array}$ & $\begin{array}{l}\text { Calculated } \\
\text { Rate of } \\
\text { Water Loss }\end{array}$ \\
\hline$t$ & (feet) & 24-hour clock) & Timed Estimated & of gallons) & (gal/min) \\
\hline
\end{tabular}

Note: Stopped drilling (TD) at because of plugged bit and caving problems. Hole continued to take water as shown through 10/31.

0450
0745
0915
1100
1130
1250

Note: At 1410 hole begins to make water; possibly because casing in alluvial section displaces water in hole 1445

Note: Hole begins to take water again when pump is shut off.

$$
1825
$$

Water additions during night not recorded; but pit kept full preparatory to temperature logging of hole.

Cleaned out

0830

Note: Hole sucked pit dry; static water level 11 feet 7 inches below drilling table ( 7 feet below ground level).

$10 / 31$

820

0900

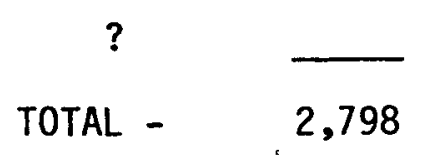


Appendix A (continued)

I

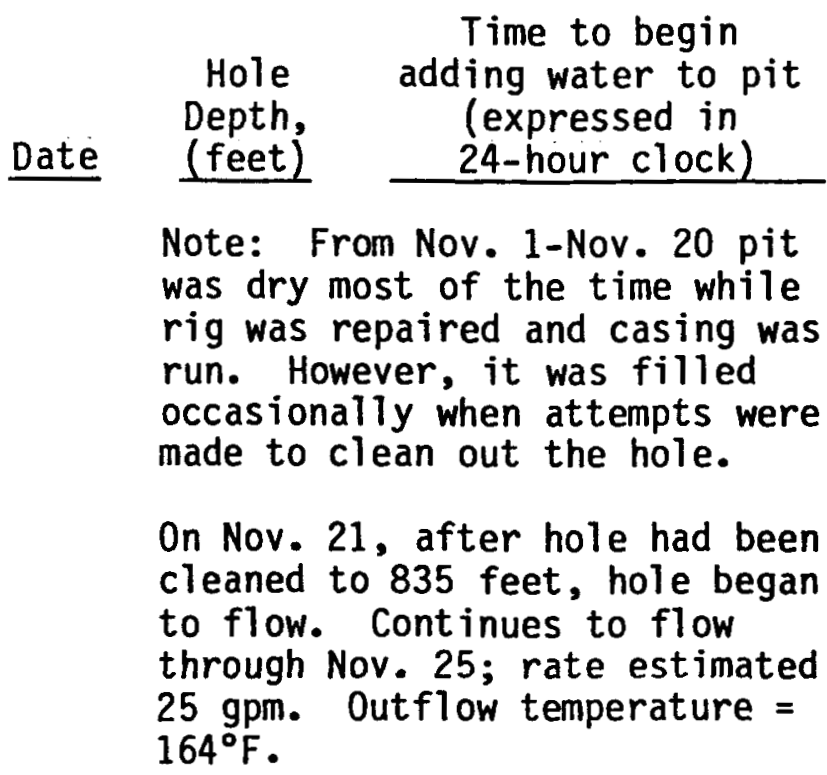

${ }^{1}$ No metered flow rate available. Pump rate estimated $80-90 \mathrm{gpm}$; assumed $80 \mathrm{gpm}$ for computation. 


\author{
APPENDIX B \\ Chemical analyses of water from Susan 1, Suzy 9A, \\ and nearby wells.
}


Appendix B. Chemical analyses of water from Susan 1, Suzy 9A, and nearby wells.

\begin{tabular}{|c|c|c|c|c|c|c|c|c|c|c|c|c|c|c|c|c|c|}
\hline \multirow[b]{2}{*}{$\begin{array}{l}\text { Sample } \\
\text { Number }\end{array}$} & \multirow[b]{2}{*}{$\begin{array}{l}\text { Sample } \\
\text { Date }\end{array}$} & \multirow[b]{2}{*}{$\begin{array}{c}\text { Temperature, } \\
{ }^{\circ} \mathrm{F}\end{array}$} & \multicolumn{11}{|c|}{ Concentration, in parts per million } & \multirow{2}{*}{$\begin{array}{l}\text { Calculated } \\
\text { TDS }\end{array}$} & \multirow[b]{2}{*}{$\begin{array}{c}\text { Field } \\
\mathrm{pH}\end{array}$} & \multirow[b]{2}{*}{$\begin{array}{l}\text { Lab } \\
\text { pH }\end{array}$} & \multirow[b]{2}{*}{ Water Type } \\
\hline & & & $\mathrm{Na}^{+}$ & $\mathrm{Ca}^{++}$ & $\mathrm{Mg}^{++}$ & $\mathrm{K}^{+}$ & $\mathrm{Cl}^{-}$ & $\mathrm{SO}_{4}$ & $\mathrm{HCO}_{3}$ & $\mathrm{CO}_{3}$ & $\mathrm{OH}^{-}$ & B & $\mathrm{SiO}_{2}$ & & & & \\
\hline $\begin{array}{l}\text { Suzy } \\
9 A-1\end{array}$ & $2 / 15 / 80^{3}$ & 165 & 215 & 76 & 2 & 5 & 120 & 320 & 34 & 0 & & 2.00 & - & 757 & 6.5 & 8.1 & \\
\hline $\begin{array}{l}\text { Suzy } \\
9 A-3\end{array}$ & $2 / 27 / 80^{3}$ & 165 & 205 & 32 & 1 & 6 & 120 & 294 & 37 & 1 & & 3.08 & - & 680 & 6.5 & 8.4 & \\
\hline $\begin{array}{l}\text { Suzy } \\
9 A-4\end{array}$ & $2 / 27 / 80^{3}$ & 165 & 203 & 30 & 1 & 6 & 119 & 294 & 35 & 1 & & 2.46 & - & 674 & 6.5 & 8.4 & $\begin{array}{l}\mathrm{Na}>>C \mathrm{C}>>\mathrm{K} \\
\mathrm{SO}_{4}>C \mathrm{Cl} \gg \mathrm{HCO}_{3}\end{array}$ \\
\hline $\begin{array}{l}\text { Suzy } \\
9 A-5\end{array}$ & $2 / 27 / 80^{3}$ & 165 & 207 & 36 & 1 & 6 & 120 & 307 & 35 & 0 & & 3.04 & - & 698 & 6.5 & 8.2 & \\
\hline $\begin{array}{l}\text { Suzy } \\
9 A-6\end{array}$ & $2 / 27 / 80^{3}$ & 165 & 205 & 34 & 1 & 6 & 119 & 301 & 37 & 0 & & 3.04 & - & 688 & 6.5 & 8.3 & \\
\hline Susan 1 & $11 / 23 / 80^{4}$ & 164 & 245 & 30 & 0.351 & 6.80 & 127 & 379 & & 7.80 & 2.52 & & 82.6 & 881 & & 8.91 & $\begin{array}{l}\mathrm{Na} \gg(\mathrm{Ca}\rangle>\mathrm{K} \\
\left.\mathrm{SO}_{4}>C \mathrm{l}\right\rangle>\mathrm{CO}_{3}\end{array}$ \\
\hline
\end{tabular}


GeothermEx, Inc.

Notes to Appendix B:

${ }^{1} \mathrm{HCO}_{3}$ calculated from total alkalinity reported as $18 \mathrm{mg} / 1 \mathrm{CaCO}_{3}$

${ }^{2}$ Value reported for $\mathrm{CO}_{3}$ inconsistent with reported $\mathrm{pH}$ of 7.1 .

${ }^{3}$ Source of data: U. S. Bureau of Reclamation pump test.

${ }^{4}$ Source of data: Sampled by GeothermEx, Inc., Analyst: American Technical Laboratories, Inc. 


$$
\begin{aligned}
& \text { Appendix B, Part 2. Ionic ratios of water from Susan 1, } \\
& \text { Suzy } 9 A \text {, and nearby wells. }
\end{aligned}
$$

Sample Number Sample Date $\mathrm{Na} / \mathrm{Ca} \quad \mathrm{Na} / \mathrm{K} \quad \mathrm{SO}_{4} / \mathrm{Cl}$

\begin{tabular}{lrrrr}
\hline $9 A-1$ & $2 / 15 / 80$ & 2.829 & 43.00 & 2.667 \\
$9 A-3$ & $2 / 27 / 80$ & 6.406 & 34.17 & 2.450 \\
$9 A-4$ & $2 / 27 / 80$ & 6.767 & 33.83 & 2.471 \\
$9 A-5$ & $2 / 27 / 80$ & 5.750 & 34.50 & 2.558 \\
$9 A-6$ & $2 / 27 / 80$ & 6.029 & 34.17 & 2.529 \\
Susan 1 & $11 / 23 / 80$ & 8.167 & 36.03 & 2.984 \\
Susan 1 & $12 / 16 / 80$ & 1.113 & 2.073 & not determined
\end{tabular}

Roosevelt

Swimming

Pool

$7 / 18 / 73$

1.053

5.882

5.500

LDS Church

$7 / 18 / 73$

5.833

30.43

2.969 


\section{APPENDIX $\underline{C}$}

Lithologic $\log$ of Susan 1 


\section{LITHOLOGIC LOG}

\section{SUSAN 1}

Depth of

Sample,

Feet

10

20

30

40

50

60

63
Rock

Type

Alluvium

Unit as above Consisting of

Unit as above

Consisting of

$$
\begin{aligned}
& 60 \% \text { fine sand } \\
& 20 \% \text { medium sand } \\
& 20 \% \text { grave? }
\end{aligned}
$$

Unit as above Consisting of

$60 \%$ coarse sand

$30 \%$ fine to medium gravel

$10 \%$ coarse gravel and cobbles, of mixed

lithology.

Unit as above Consisting of $40 \%$ coarse sand $30 \%$ medium to fine gravel

$30 \%$ coarse gravel and cobbles, of mixed 1 ithology

(Much larger cobbles and small boulders al so are present-- $14^{\prime \prime}$ subangular boulder fished from $52^{\prime}$ ).

Unit as above Consisting of $40 \%$ coarse sand

$40 \%$ fine to medium grave 1

$20 \%$ coarse gravel and cobbles 
Unit as above

68

Unit as above

70

Unit as above

73

80
Unit as above

Lacustrine Deposits(?)
$50 \%$ coarse sand

$40 \%$ fine to medium gravel

$10 \%$ coarse gravel and pebbles

$40 \%$ coarse sand

$50 \%$ fine to medium gravel

$10 \%$ coarse gravel and cobbles

$50 \%$ fine to medium gravel, of mixed lithologies

$20 \%$ coarse gravel and cobbles

$10 \%$ coarse sand

$30 \%$ ash or partially hydrated clay

Ash/clay is tan or pinkish-brown or white. Ranges from soft to moderately firm and brittle and relatively dry. Contains admixture of very fine $(<0.1 \mathrm{~mm})$ sand grains; red, brown, and orange.

$50 \%$ ash/clay, as above

$30 \%$ very fine sand, mixed lithology

$20 \%$ coarse sand to pebbles.

\section{[Alternative identification--} altered ash or mud flow]

Consisting of:

$70 \%$ ash/clay matrix. Pinkish brown in color, fairly firm, slightly sticky.

Component particles not resolvable at $30 x$ magnification.

$20 \%$ very fine sand, contained in ash component. Mostly black, brown, or orange nonmagnetic, some black or bronze-colored mica flakes.

$10 \%$ medium to coarse sand. 
Unit as above Overall color is pink-brown to rusty yellow. Consisting of:

$50 \%$ ash/clay matrix; in pebble-size, firm to very firm chips.

$40 \%$ very fine sand, similar to previous interval.

$10 \%$ medium to coarse sand.

Unit as above Very firm cuttings, consisting of:

$40 \%$ ash/clay matrix with very fine sand.

$40 \%$ medium to coarse sand.

$20 \%$ fine to medium gravel.

90

As above.

100

Unit as above Pebble sized, relatively hard cuttings, consisting of:

$50 \%$ very fine sand

$40 \%$ ash/clay matrix

$10 \%$ medium to coarse sand

As above.

Unit as above. Much softer.

Unit as above Soft cuttings, consisting of:

$60 \%$ ash/clay matrix with very fine sand. Tan color, very soft.

$20 \%$ fine sand

$20 \%$ ash/clay. Dark green color, hard, contains very fine sand component.

Unit as above Proportions of components about the same as above, but there is variability in overall color, ranging from oxidized red to gray-green. 
Lacustrine deposits (?) Similar to unit above, but persistent for many feet in color and hardness. [Matrix composition checked by oil immersion mount.] Sample composed of: $60 \%$ clay/ash matrix $40 \%$ very fine sand

Pebble-sized firm cuttings. Blue-gray color predominates, but tan and brown chips also present.

As above.

160

Unit as above

$$
\begin{aligned}
& 40 \% \text { clay/ash matrix } \\
& 40 \% \text { fine sand } \\
& 20 \% \text { medium sand }
\end{aligned}
$$

Unit as above

Unit as above

Greater variability of color, with both dark green and brick red coloration in same chip.

Unit as above

Increase in iron oxide color. Trace of clear calcite crystals. [Checked matrix by oil immersion mount; matrix appears identical to 140 ' sample.]

Unit as above

Medium brown cuttings, slightly softer than above.

Unit as above

Unit as above

Includes both medium-hard, blue-gray gravel-size cuttings and somewhat softer, medium-brown cuttings. Observed one possible pumice lump (much oxidized).

Unit as above Medium hard cuttings; much iron-oxide staining.

Unit as above Very oxidized. Trace of clear calcite fragments.

Unit as above Considerably softer. 
Unit as above Very soft.

90\% clay/ash matrix, bluegray color.

$10 \%$ very fine sand

Unit as above

Chips very soft; easily disaggregated to soft, white paste.

Homogeneous clay/altered ash (water-laid or airfall ash?) Gray-brown color, very soft (can easily be disaggregated to $<0.01 \mathrm{~mm}$ ). [Inspection by oil immersion mount at $400 x$ magnification shows virtually no components $>0.02$ $\mathrm{mm}$. Low birefringence; texture and mineralogy apparently same as previous samples. Darker color caused by slightly higher proportion (to 10\%) of opaques.]

As above.

Lacustrine deposits(?) Similar to 190-240' interval. Very fine-grained clay-ash matrix of variable colors, ranging from dark blue-green to orange-red. Traces of clear calcite crystals; rare small $(0.1 \mathrm{~mm})$ pyrite crystals.

As above.

Unit as above

Medium-hard cuttings, variable color; but where disaggregated, makes bright red mud.

Unit as above

Cuttings of variable hardness and color, including relatively soft, silvery-green and hard red-brown chips. Accessory small (1mm) clear calcite rhombs.

Unit as above

Predominantly medium blue-gray cuttings. Higher proportion of very fine sand. Some calcite veins.

Unit as above Disaggregates to white paste. 
Tuff(?) (Altered volcanic ash/clay). Cuttings are predominantly blue-green in color, very fine-grained, harder to disaggregate with steel pick. Trace of tiny pyrite crystals; small calcite veins. [Inspection by oil immersion mount at $400 \mathrm{x}$ magnification shows that about $50 \%$ of sample is composed of cloudy glass, but no pumice shards or other original textures are visible. $45 \%$ of sample is low birefringent $\mathrm{clay}$, easily crushed to $<0.01 \mathrm{~mm}$. Scarce very smali $(0.02 \mathrm{~mm})$ partially altered plagioclase crystals. Few clear very small $(0.02 \mathrm{~mm})$ higher birefringent chips; probably calcite.]

Unit as above

All cuttings are very fine grained. Sample composed of:

$90 \%$ blue-green phase, hard to very hard

$10 \%$ gray-brown phase, medium soft.

Unit as above

Primarily blue-green, hard phase. Accessory small (2mm) translucent calcite cleavage fragments; trace small 0.5 mm) pyrite crystals.

Unit as above

Unit as above Composed of:

90\% green to white very fine-grained phase; medium hard.

$10 \%$ gray-brown phase; soft

Unit as above Composed of:

70\% gray-green phase, as in 320-330' interval. Hard.

$30 \%$ gray-brown phase. Soft. Slightly less homogeneous-contains tiny soft white patches.

No sample. 
Unit as above Composed of:

\author{
$80 \%$ gray-green phase, \\ medium hard to hard. \\ $20 \%$ pink to red-oxidized \\ fine-grained phase. \\ Soft to medium hard. \\ Contains abundant very \\ fine $(<0.1 \mathrm{~mm})$ multico- \\ lored lithic frag- \\ ments. \\ Accessory calcite \\ fragments; trace \\ pyrite.
}

As above.

As above.

$80 \%$ gray-green phase, hard to medium hard.

$10 \%$ gray-brown phase, soft

$10 \%$ pink to tan phase. Soft, mainly finegrained phase but contains very fine multicolored lithic fragments.

Accessory clear calcite crystals.

[Inspection of oil immersion mount at 400x shows gray-green phase composed of $60 \%$ very fine $(0.01 \mathrm{~mm})$ low birefringence clay, $40 \%$ cloudy structureless glass.]

As above. 
Unit as above Composed of:

$$
\begin{aligned}
& \text { 80\% gray-green phase, } \\
& \text { hard. } \\
& 20 \% \text { soft gray paste. } \\
& \text { Disaggregated } \\
& \text { clay/ash? }
\end{aligned}
$$

[Core from Suzy 9A at 390-394.3 feet was reported to be medium-gray to gray-green to green; har, dense, but could be scratched with knife. Groundmass: medium gray-green, fine-grained. Clasts: lightgray to medium gray-green, fine-grained, angular to subrounded, size fine to up to $3^{\prime \prime}$. Cormon calcite veins and vein fillings; common pyrite.]

Unit as above Composed of:

$70 \%$ gray-green phase; medium hard to hard.

$20 \%$ gray-brown phase; soft

$10 \%$ tan to orange oxidized phase; medium soft. Accessory vein calcite, with pyramidally terminated crystals.

Unit as above Composed of:

50\% gray-green phase; hard to medium hard.

$30 \% \tan$ to orange oxidized phase

$20 \%$ vein-filling calcite

Accessory gray-brown phase; soft

Unit as above Composed of:

90\% gray-green phase; medium hard to hard

$10 \% \tan$ to orange oxidized phase

Accessory calcite

Unit as above Composed of:

70\% gray-green phase; hard to medium hard

$20 \%$ tan to orange oxidized phase

$10 \%$ vein calcite. 
Unit as above Composed of:

90\% gray-green phase; hard

$10 \% \tan$ to orange oxidized phase

Accessory calcite

445 Unit as above Composed of:

80\% gray-green phase; hard

$10 \%$ tan to orange oxidized phase

$10 \%$ gray paste; soft. Disaggregated clay/ash?

Accessory calcite

Unit as above Composed of:

$80 \%$ gray-green phase; hard

$20 \%$ gray-brown phase; soft

454 Unit as above Composed of:

70\% gray-green phase; medium hard to hard

$30 \%$ gray paste; soft. Disaggregated clay/ash?

460 Unit as above Composed of:

60 gray-green phase; medium hard to hard

$20 \% \tan$ to orange oxidized phase

10\% gray-brown phase; soft

$10 \%$ calcite 
Altered andesite. (erratic boulder?) Sample composed of:

$90 \%$ andesite. Dark gray, very hard cuttings.

$10 \%$ tan to brown phase;

altered volcanics.

[Inspection of oil immersion mount at $100 x$ and $400 x$ shows some small hornblende crystals. Ground mass partially glassy; partially altered to clay.] Probably erratic boulder because of small thickness.

Tuff(?) (Altered volcanic ash/clay) Composed of:

$70 \%$ gray-green phase; hard. Similar to 400-450' interval.

$20 \%$ soft gray paste. Disaggregated clay/ash.

$10 \%$ tan to brown phase. Clay/ash.

Unit as above Composed of:

$60 \%$ soft gray paste. Disaggregated clay/ash.

40\% gray-green phase; hard. Similar to 468' interval.

Unit as above Composed of:

90\% gray-green phase; medium hard to hard. Thin film of yellowgreen alteration mineral (epidote?)

$10 \%$ tan to brown phase. Accessory calcite

Unit as above Composed of:

40\% dark gray andesite, similar to $465^{\prime}$ interval

$50 \%$ soft clay/ash of various colors, including white, tan, sulfur-yellow.

$10 \%$ calcite. 
Unit as above Composed of:
$60 \%$ gray-green phase; hard
$30 \%$ tan to orange oxi- dized phase
$10 \%$ calcite

Unit as above Composed of:

90\% gray-green phase; hard $10 \%$ soft gray clay/ash

Unit as above Composed of:

90\% gray-green phase; hard $10 \%$ tan phase; soft

Accessory calcite

500 Unit as above Composed of:
$50 \%$ gray-green phase; hard $20 \%$ tan phase; soft
$20 \% \tan$ to orange oxidized phase; hard
$10 \%$ calcite

[Core from Suzy 9A at 507-511.5 feet was reported to be light to medium gray to gray-green, dense to fractured, fractures mostly healed with white calcite; some slickens apparent. Groundmass: light gray to gray-green, very soft and flaky to moderately firm; can be scratched in places with fingernail, others only with knife. Fine to medium-grained, common hornblende and recrystallized calcite. Clasts: light to medium gray, usually hard and aphanitic; angular to subrounded, up to $3^{\prime \prime}$ in size. Large voids filled with white calcite. Common pyrite.]

Unit as above Composed of:

90\% gray-green phase; hard $10 \%$ soft gray paste (disaggregated clay/ash)

515 As above 
Unit as above Composed of:

$60 \%$ gray-green phase; hard

$20 \%$ tan clay/ash phase; soft

$20 \%$ soft gray paste

(disaggregated clay/ash)

525

As above

530

Unit as above Composed of:

80\% gray-green phase; hard

$10 \%$ tan clay/ash phase; soft

$10 \%$ red and brown oxidized phase

540

No sample

550

Unit as above Composed of:

$80 \%$ gray-green phase; hard

$20 \%$ gray-brown to tan phase; soft (includes some paste-- disaggregated clay/ash)

Unit as above Composed of:

90\% gray-green phase; hard

$10 \%$ soft gray paste (disaggregated clay/ash)

Accessory calcite; trace pyrite

$570 \quad$ Unit as above Composed of:

$80 \%$ gray-green phase; hard

$10 \%$ gray-green to tan phase; soft

$10 \%$ soft gray paste (disaggregated clay/ash)

580 Unit as above Composed of:

90\% gray-green phase; hard 10\% brown phase; soft Trace calcite 
Unit as above Composed of:

$80 \%$ gray-green phase; hard

$10 \%$ gray-green phase; soft

10\% gray-brown phase; soft

Trace calcite

590

Unit as above Composed of:

90\% gray-green phase; hard 10\% gray-brown phase; soft (Sample covered with soft

gray paste-- disaggregated clay/ash)

600

Unit as above Composed of:

90\% gray-green phase;

hard. About $1 / 2$ of

chips have thin patches of yellowgreen, amorphous alteration mineral.

$10 \%$ tan to orange oxidized phase; hard

Accessory calcite

605

Unit as above Composed of:

90\% gray-green phase; hard $10 \%$ gray-brown phase; soft Accessory calcite

Unit as above Composed of:

90\% gray-green phase; hard. Films of yellow-green alteration mineral common (epidote?)

10\% calcite. Translucent cleaveage fragments, probably vein-filling.

615 Unit as above Composed of:

80\% gray-green phase; hard. Yellow-green alteration mineral (epidote?) is common.

$20 \%$ calcite-- clear veinfillings. 
Unit as above Composed of:

90\% gray-green phase; hard. Yellow-green alteration common.

10\% red-brown phase; soft. Contains some lithic fragments.

Accessory calcite

Unit as above Composed of:

$80 \%$ gray-green phase; hard. Yellow-green alteration less common.

$15 \%$ calcite

$5 \%$ red-brown phase; hard

630

Unit as above Composed of:

90\% gray-green phase; hard. Yellow-green alteration mineral sparse.

$5 \%$ calcite

$5 \%$ gray-brown phase; soft

As above

Unit as above Composed of:

90\% gray-green phase; medium hard.

$10 \%$ gray-brown phase; soft

656

Unit as above Composed of:

90\% gray-green phase; hard. Sparse yellowgreen alteration

$10 \%$ gray-brown or tan soft clay/ash

Accessory calcite

Unit as above Composed of:

95\% gray-green phase; hard

$5 \%$ soft $\tan$ clay/ash 
Unit as above Composed of:

90\% gray-green phase; medium hard to hard

$10 \%$ soft gray paste (disaggregated clay/ash)

Unit as above Composed of:

90\% gray-green phase; hard

$10 \%$ soft red-brown, orange, and gray-brown $\mathrm{ash} / \mathrm{clay}$

As above

Unit as above Composed of:
$90 \%$ gray-green phase; medium hard to hard. Sparse yellow-green alteration
$10 \%$ soft brown and orange ash/clay

[Core form Suzy 9A at 682.5-687 feet reported to be light to dark gray to black, hard, but can be scratched locally with a knife. Dense but locally fractured. Fractures and voids healed or partially filled from two events of secondary mineralization: white calcite first and white to clear, crystalline quartz secondly. Matrix aphanitic, dark gray to black with vug fillings of feldspar and calcite. Clasts light to dark gray, hard, angular to subrounded, fine up to 1 "]

Unit as above Composed of:

$80 \%$ gray-green phase; medium-hard to hard 10\% gray-brown phase; soft $10 \%$ tan to orange ash/clay Accessory calcite 
Unit as above Composed of:

$80 \%$ gray-green phase; medium hard to hard

$10 \%$ gray-brown phase; soft

$10 \%$ soft gray paste

700

Unit as above Composed of:

$90 \%$ gray-green phase;

hard. Sparse yellowgreen alteration.

$10 \%$ gray-brown phase; soft

Accessory calcite

Unit as above Composed of:

$80 \%$ gray-green phase;

hard. As above.

$10 \% \tan$ to brown ash/clay and soft gray paste

$10 \%$ gray-brown phase; soft

$710 \quad$ Lake beds(?) Composed of:

$50 \%$ soft gray paste (disaggregated ash)

40\% gray-green phase; hard

$10 \%$ gray-brown phase; soft

715 Unit as above Composed of:

$40 \%$ gray-green phase; hard

$40 \%$ hard dark gray to

black andesite, similar to $465^{\prime}$ interval

$10 \%$ soft red, tan, brown clay/ash

Unit as above Composed of:

$80 \%$ gray-green phase; hard

$20 \%$ soft white paste

Unit as above Composed of:

40\% gray-brown phase; soft. Contains some fine sand.

40\% gray-green phase; hard

$20 \%$ soft white paste 
Unit as above Composed of:

$40 \%$ gray-green phase; hard

$40 \%$ white paste and fine sand

$20 \%$ gray-brown phase; soft, as above

Trace pyrite crystals

Unit as above Composed of:

$50 \%$ soft gray paste

$30 \%$ gray-green phase; hard

$20 \%$ gray-brown phase; soft

745 Unit as above Composed of:

$70 \%$ gray-green phase; hard. Some pyrite.

$20 \%$ soft to medium hard red ash/clay

$10 \%$ white paste

Basaltic Andesite, medium gray.

$90 \%$ medium hard, medium gray andesite, containing $1 \mathrm{~mm}$ altered plagioclase phenocrysts. Also fine pyrite crystals and some dark green alteration.

$10 \%$ soft sandy red-brown ash/clay.

Accessory calcite, including veins in andesite

Unit as above

90\% hard medium-gray andesite with pyrite and sparse yellow-green alteration (epidote?)

$10 \%$ gray-brown phase; soft Accessory calcite

As above 
Unit as above Composed of:

90\% light gray to pale green ash/clay. Common tiny pyrite crystals, little or no epidote or dark green alteration minerals. No phenocrysts noted.

$10 \% \tan$ to red-brown ash/clay, medium hard.

Unit as above

$90 \%$ andesite, hard, medium gray. Common yellowgreen alteration (epidote?)

$10 \%$ soft $\tan$ ash/clay

$775 \quad$ Unit as above

$90 \%$ andesite, hard, medium gray. Sparse yellowgreen alteration.

$5 \%$ calcite

$5 \%$ gray-brown phase; soft

Unit as above

$80 \%$ andesite as above

$10 \%$ calcite

$10 \% \tan$ to orange clay/ash

Unit as above

70\% gray-green ash/clay, as in $765^{\prime}$ interval.

$20 \%$ tan to orange ash/clay

$10 \%$ calcite

Unit as above

$50 \%$ andesite as in
$770-780$ interval
$20 \%$ tan to orange
ash/clay, soft
$20 \%$ gray-brown phase; soft
$10 \%$ calcite
Accessory pyrite




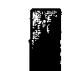

Unit as above

$80 \%$ andesite, as above $20 \%$ tan to orange-stained clay/ash, as above Accessory calcite

$80 \%$ light gray to graygreen phase; medium hard to hard. No phenocrysts, no lithic fragments noted.

$20 \%$ gray-brown phase; soft Some soft gray paste (disaggregated ash/clay)

$815 \quad$ Unit as above

$70 \%$ light gray to graygreen phase; medium hard to hard. Has tiny pyrite crystals.

$30 \%$ gray-brown phase; soft

$820 \quad$ Unit as above Very soft.

$50 \%$ soft gray paste (disaggregated ash/clay)

$30 \%$ light gray to graygreen phase; soft to medium hard 
$70 \%$ light gray to graygreen phase; medium hard to hard.

$20 \%$ gray-brown phase; soft

$10 \%$ tan to orange-stained clay/ash

Unit as above

$80 \%$ light gray to graygreen phase; medium hard to hard.

$10 \%$ gray-brown phase; soft

$10 \%$ tan to orange-stained clay/ash

Accessory pyrite

835

Unit as above

$70 \%$ light gray to graygreen phase; medium hard to hard.

$20 \%$ gray-brown phase; soft

$10 \%$ tan to orange-stained clay-ash

840

Unit as above

$80 \%$ light gray to graygreen phase; medium hard to hard.

10\% gray-brown phase; soft

$10 \%$ soft gray paste (disaggregated clay/ash)

842

Unit as above

$60 \%$ light gray to graygreen phase; medium hard to hard. Some yellow-green alteration.

$10 \%$ yellow to $\tan$ soft ash/clay

$10 \%$ andesite, hard, dark gray

$10 \%$ calcite

$10 \%$ gray-brown phase; soft 
$50 \%$ light gray to graygreen phase; medium hard to hard.

$20 \%$ gray-brown phase; soft

$20 \%$ yellow to $\tan$ soft ash/clay

$10 \%$ calcite

850

Unit as above

$90 \% 1$ ight gray to graygreen phase; medium hard to hard. Abundant pyrite crystals but not yellow-green alteration noted.

$10 \%$ calcite

855

Unit as above

$90 \% 1$ ight gray to graygreen phase; medium hard to hard. Some yellow-green alteration and some pyrite.

$10 \%$ gray-brown phase; soft

860

Unit as above

$60 \%$ light gray to graygreen phase; medium hard to hard.

40\% gray-brown phase; soft Accessory calcite

Unit as above

$70 \%$ light gray to graygreen phase; medium hard to hard. Sparse pyrite.

$30 \%$ gray-brown phase; soft

880

Unit as above

$60 \%$ light gray to graygreen phase; medium hard to hard.

40\% gray-brown phase; soft 
Unit as above

$100 \%$ tan to gray ash/clay phase; medium hard to hard. Common pyrite. Color facies of previous units?

890

Unit as above

$80 \%$ tan to gray phase, as above

$20 \%$ gray-brown phase; soft

895

Basalt or basaltic andesite

$80 \%$ dark gray basaltic andesite or basalt. Classy, densetextured, contains plagioclase phenocrysts with carlsbad twinning $(0.5-1 \mathrm{~mm})$. Calcite and pyrite on fracture surfaces.

$20 \%$ tan to gray phase, as above.

$897 \quad$ Unit as above

$50 \%$ dark gray basalt, as above

$30 \%$ light gray ash/clay phase

10\% gray-brown phase; soft

900

Unit as above

$70 \%$ dark gray basalt, as above. Many healed fractures, filled with calcite, pyrite

$20 \%$ gray-brown phase; soft $10 \%$ vein calcite 
$50 \%$ dark gray basalt, as above. Sparse yellowgreen alteration on fractures.

$20 \%$ gray-brown phase; soft

$10 \%$ multicolored soft ash/clay

$10 \%$ light gray to graygreen phase; medium hard to hard.

$10 \%$ calcite

Unit as above

$60 \%$ light gray to graygreen phase; medium hard to hard. Some yellow-green alteration on fracture surfaces; common pyrite

$30 \%$ gray-brown phase; soft

$10 \%$ calcite

$50 \%$ gray-brown phase; soft

$20 \%$ light gray to graygreen phase; medium hard to hard.

$20 \%$ soft multicolored ash/clay

10\% calcite

Unit as above

$70 \%$ gray-brown phase; soft

$30 \%$ light gray to graygreen phase; medium hard to hard. 
APPENDIX D

Results of Pump Test of Susan 1, December 4-5, 1980. 


\section{Appendix D}

Results of pump test of Susan 1, December 4-5, 1980 .

Note: Water level referred to depth below porthole in casing, which is $\overline{4.42}$ feet below ground level. Flowing temperature of water stabilized at $174^{\circ} \mathrm{F}$ during entire test. Pump was set at 250 feet below ground level.

\begin{tabular}{|c|c|c|c|}
\hline $\begin{array}{l}\text { Water Level } \\
\text { Below Ground }\end{array}$ & $\begin{array}{l}\text { Water Level } \\
\text { Below Porthole } \\
\text { in Casing, }\end{array}$ & Time of & $\begin{array}{l}\text { Minutes Elapsed } \\
\text { Since Pump }\end{array}$ \\
\hline
\end{tabular}

Start pump at 1550 hours, December 4. Pump Rate $250 \mathrm{gpm}-\cdots-$

\begin{tabular}{|c|c|c|c|}
\hline 19' $11^{\prime \prime}$ & 15.50 & 1620 & 30 \\
\hline $20^{\prime} \quad 8^{\prime \prime}$ & 16.25 & 1645 & 55 \\
\hline $20^{\prime} \quad 4^{\prime \prime}$ & 15.91 & 1700 & 70 \\
\hline 20' 9" & 16.33 & 1715 & 85 \\
\hline 20' 9" & 16.33 & 1730 & 100 \\
\hline $21^{\prime} \quad 4 "$ & 16.91 & 1745 & 115 \\
\hline $27^{\prime} \quad 6 "$ & 17.08 & 1800 & 130 \\
\hline $21^{\prime} \quad 7 "$ & 17.16 & 1815 & 145 \\
\hline $21^{\prime} \quad 7 "$ & 17.16 & 1830 & 160 \\
\hline 21 ' $10^{\prime \prime}$ & 17.41 & 1845 & 175 \\
\hline $21^{\prime} \quad 8 "$ & 17.25 & 1900 & 190 \\
\hline $21^{\prime} \quad 8 "$ & 17.25 & 1915 & 205 \\
\hline $21^{\prime} 10^{\prime \prime}$ & 17.41 & 1930 & 220 \\
\hline $21^{\prime} \quad 9 "$ & 17.33 & 1945 & 235 \\
\hline $21^{\prime} \quad 9 "$ & 17.33 & 2000 & \\
\hline
\end{tabular}


Appendix D (continued)

\begin{tabular}{|c|c|c|c|}
\hline $\begin{array}{l}\text { Water Level } \\
\text { Below Ground }\end{array}$ & $\begin{array}{c}\text { Water Level } \\
\text { Below Porthole } \\
\text { in Casing, } \\
\text { Feet }\end{array}$ & $\begin{array}{c}\text { Time of } \\
\text { Observation }\end{array}$ & $\begin{array}{l}\text { Minutes Elapsed } \\
\text { Since Pump } \\
\text { Turned On or off }\end{array}$ \\
\hline
\end{tabular}

\begin{tabular}{|c|c|c|c|c|}
\hline $9^{\prime}$ & $8^{\prime \prime}$ & 5.25 & 2001 & 1 \\
\hline & $8 "$ & 5.25 & 2002 & 2 \\
\hline $8^{\prime}$ & 6" & 4.08 & 2003 & 3 \\
\hline $7 '$ & 9" & 3.33 & 2004 & 4 \\
\hline 79 & $7 "$ & 3.16 & 2005 & 5 \\
\hline $7^{\prime}$ & 4" & 2.91 & 2006 & 6 \\
\hline & 2" & 2.75 & 2007 & 7 \\
\hline 71 & $0^{\prime \prime}$ & 2.58 & 2008 & 8 \\
\hline $6^{\prime}$ & $10^{\prime \prime}$ & 2.41 & 2009 & 9 \\
\hline $6^{\prime}$ & 8" & 2.25 & 2010 & 10 \\
\hline $6^{\prime}$ & 4" & 1.91 & 2001 & 11 \\
\hline $5^{\prime}$ & 4" & $0.91^{1}$ & 2030 & 30 \\
\hline
\end{tabular}

$\begin{array}{lllll}29^{\prime} & 9 " & 25.33 & 2115 & 15 \\ 30^{\prime} & 4 " & 25.91 & 2130 & 30 \\ 32^{\prime} & 3 " & 27.83 & 2145 & 45 \\ 33^{\prime} & 5^{\prime \prime} & 29.00 & 2200 & 60 \\ 33^{\prime} & 7 " & 29.16 & 2215 & 75 \\ 33^{\prime} & 9 " & 29.33 & 2230 & 90\end{array}$




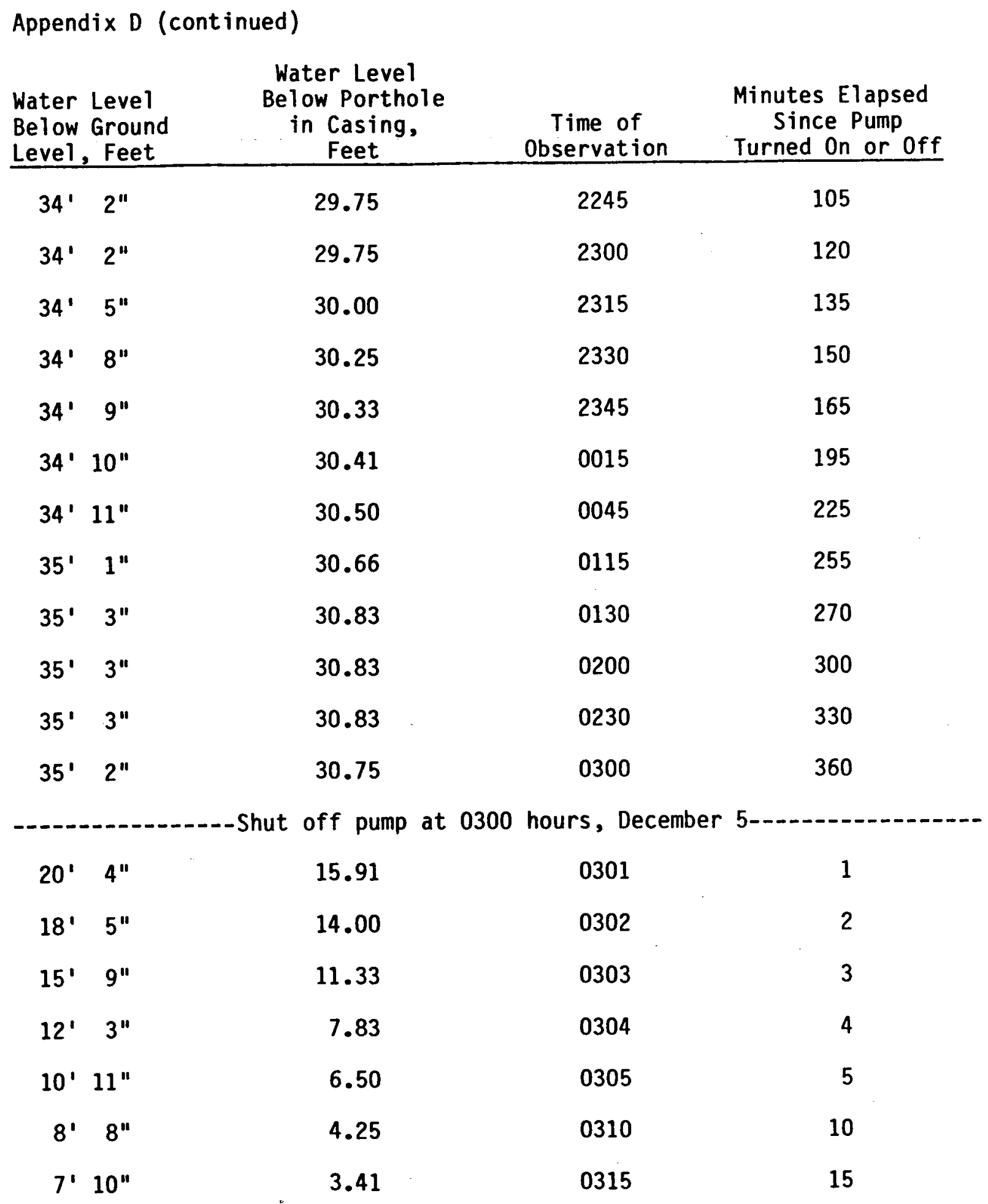


Appendix D (continued)

\begin{tabular}{|c|c|c|c|c|}
\hline $\begin{array}{l}\text { Water } \\
\text { Bel ow } \\
\text { Level }\end{array}$ & $\begin{array}{l}\text { Leve1 } \\
\text { Ground } \\
\text { Feet } \\
\end{array}$ & $\begin{array}{c}\text { Water Level } \\
\text { Below Porthole } \\
\text { in Casing, } \\
\text { Feet }\end{array}$ & $\begin{array}{c}\text { Time of } \\
\text { Observation }\end{array}$ & $\begin{array}{l}\text { Minutes Elapsed } \\
\text { Since Pump } \\
\text { Turned On or off }\end{array}$ \\
\hline $7^{\prime}$ & $3 "$ & 2.83 & 0320 & 20 \\
\hline & $8^{\prime \prime}$ & 2.25 & 0325 & 25 \\
\hline & $2^{\prime \prime}$ & 1.75 & 0330 & 30 \\
\hline & $0^{\prime \prime}$ & 1.58 & 0335 & 35 \\
\hline & $8^{\prime \prime}$ & 1.25 & 0350 & 50 \\
\hline $5^{\prime}$ & 6" & 1.08 & 0405 & 65 \\
\hline $5^{\prime}$ & 4" & 0.91 & 0420 & 80 \\
\hline $5^{\prime}$ & $3 !$ & 0.83 & 0450 & 110 \\
\hline & $1 "$ & 0.66 & 0520 & 140 \\
\hline $4^{\prime}$ & $11^{\prime \prime}$ & 0.50 & 0550 & 170 \\
\hline $4^{\prime}$ & 8" & 0.25 & 0620 & 200 \\
\hline $4^{\prime}$ & 5" & 0.0 & $0650^{2}$ & 230 \\
\hline
\end{tabular}

Start pump at 0655 hours, December 5. Pump Rate $150 \mathrm{gpm}--------$

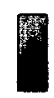

$\begin{array}{rrrrr}5^{\prime} & 10^{\prime \prime} & 1.41 & 0655 & 1 \\ 16^{\prime} & 4 " & 11.91 & 0700 & 5 \\ 18^{\prime} & 1^{\prime \prime} & 13.66 & 0715 & 20 \\ 19^{\prime} & 0^{\prime \prime} & 14.58 & 0730 & 35 \\ 19^{\prime} & 3 " & 14.83 & 0745 & 50 \\ 19^{\prime} & 0^{\prime \prime} & 14.58 & 0800^{3} & 65\end{array}$

------No detailed data available for $650 \mathrm{gpm}$ pump rate--see note 4.---.--- 
Appendix $D$ (continued)

Footnotes:

$1_{\text {Water level reported to attain rest level } 1 \text { hour after pump was turned }}$ off.

${ }^{2}$ progress report by $P$. A. Edwardes indicates that rest level was attained 1 hour 20 minutes after pump was turned off. However, detailed report of test indicates that reaching rest level required 3 hours 50 minutes.

3 progress report by $P$. A. Edwardes states that rest level was attained for $150 \mathrm{gpm}$ pump rate at 1 hour 15 minutes after pump was turned off.

${ }^{4}$ Progress report by $P$. A. Edwardes states that stable drawdown at $650 \mathrm{gpm}$ was 83 feet below ground level, and that rest level was attained 1 hour 20 minutes after pump was turned off. 


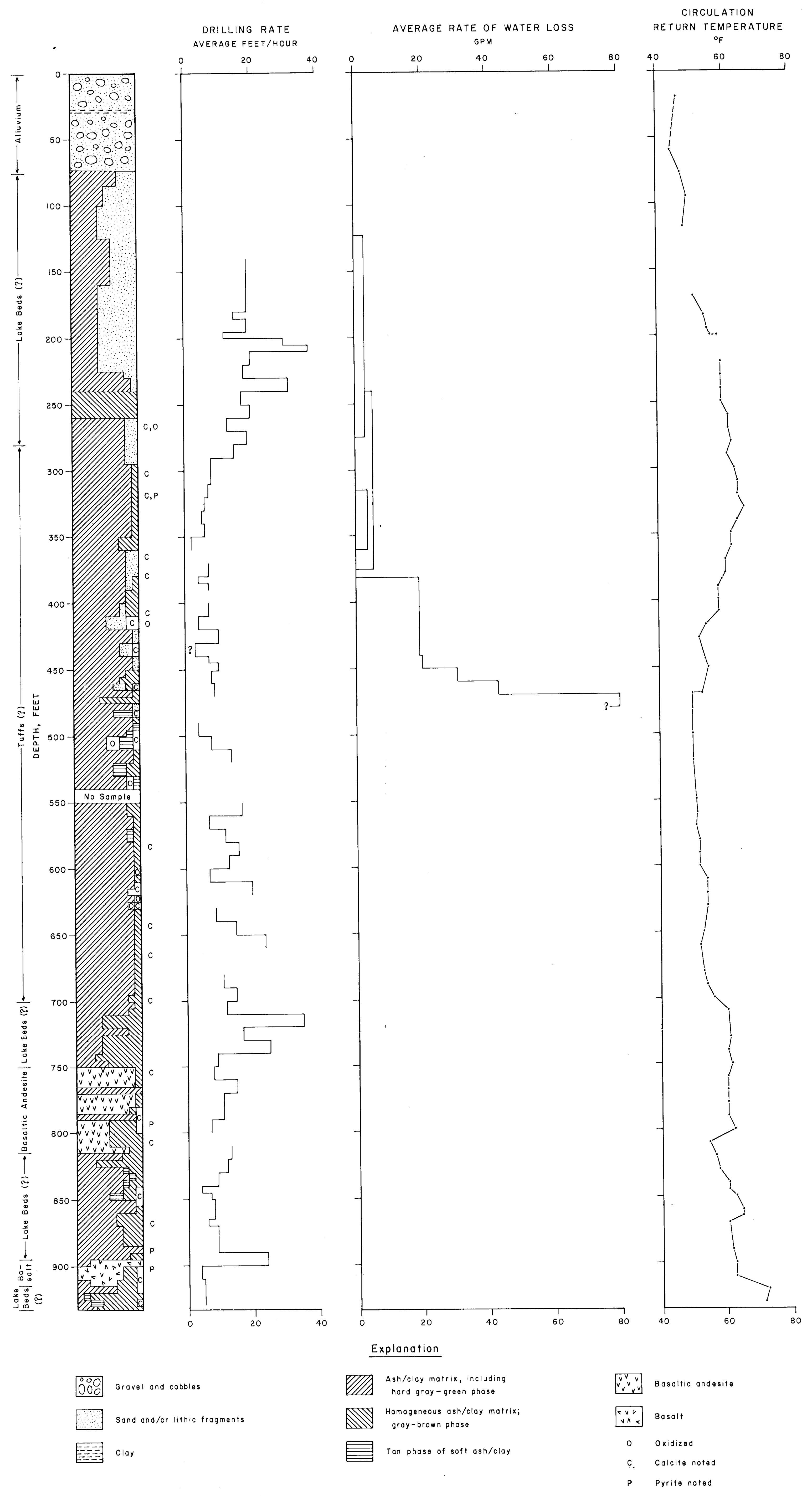

PLATE I. Lithology, drilling rate, and mud return temperatures of Susan 1. 


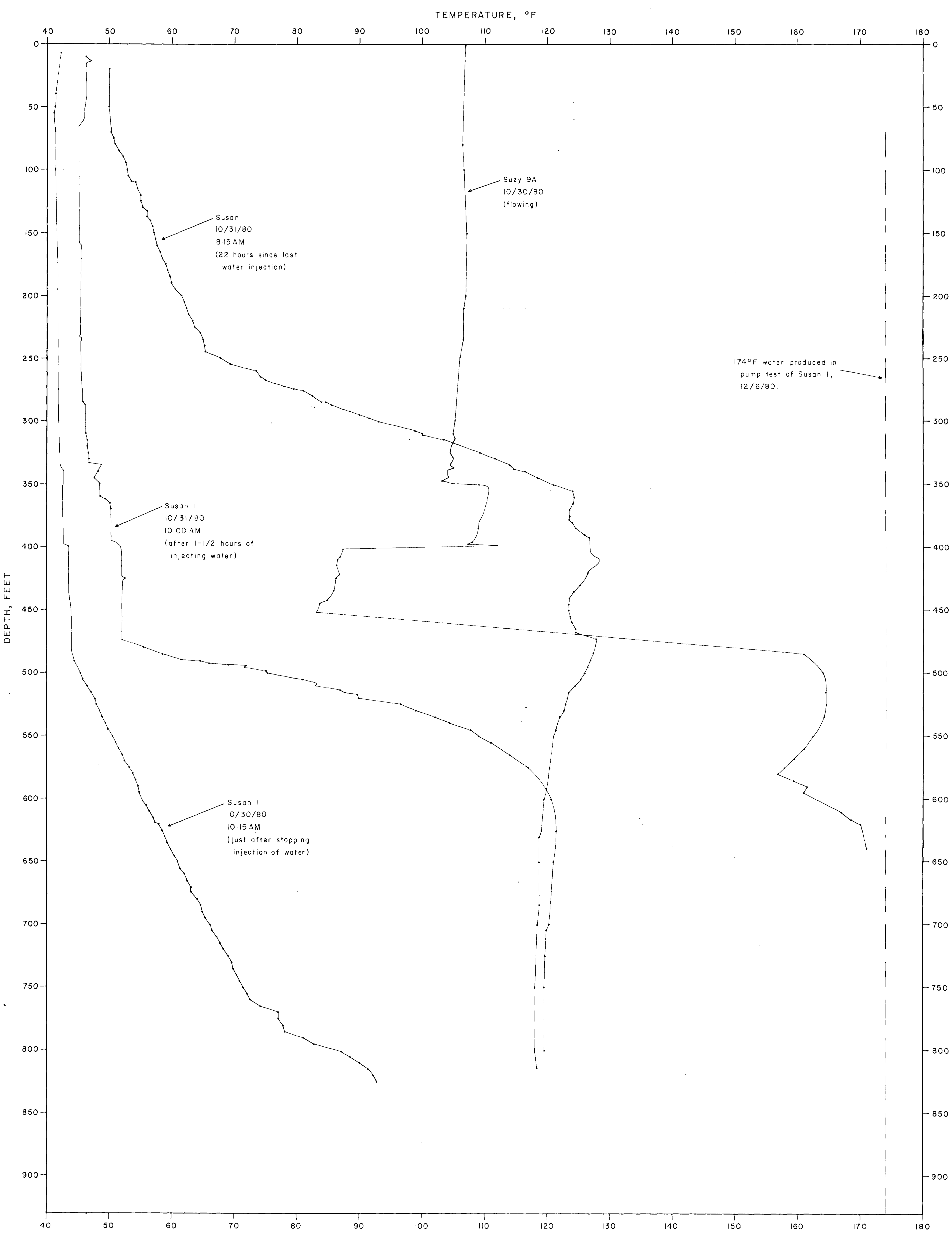

PLATE 2. Temperature logs of Susan 1 and Suzy $9 A$. 